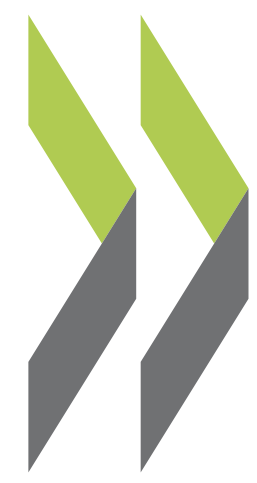

OECD Economics Department Working Papers No. 1421

Corporate governance and firm performance

in China
Margit Molnar,

Baolin Wang,

Wenhao Chen 
Organisation de Coopération et de Développement Économiques

Organisation for Economic Co-operation and Development

10-Oct-2017

ECONOMICS DEPARTMENT

English - Or. English

CORPORATE GOVERNANCE AND FIRM PERFORMANCE IN CHINA

ECONOMICS DEPARTMENT WORKING PAPERS No. 1421

By Margit Molnar, Wenhao Chen and Baolin Wang

OECD Working Papers should not be reported as representing the official views of the OECD or of its member countries. The opinions expressed and arguments employed are those of the author(s).

Authorised for publication by Alvaro Pereira, Director, Country Studies Branch, Economics Department.

All Economics Department Working Papers are available at www.oecd.org/eco/workingpapers.

This document, as well as any data and map included herein, are without prejudice to the status of or sovereignty over any territory, to the delimitation of international frontiers and boundaries and to the name of any territory, city or area. 
OECD Working Papers should not be reported as representing the official views of the OECD or of its member countries. The opinions expressed and arguments employed are those of the author(s).

Working Papers describe preliminary results or research in progress by the author(s) and are published to stimulate discussion on a broad range of issues on which the OECD works.

Comments on Working Papers are welcomed, and may be sent to OECD Economics Department, 2 Rue André-Pascal, 75775 Paris Cedex 16, France, or by e-mail to eco.contact@ oecd.org.

All Economics Department Working Papers are available at www.oecd.org/eco/workingpapers.

This document and any map included herein are without prejudice to the status of or sovereignty over any territory, to the delimitation of international frontiers and boundaries and to the name of any territory, city or area.

The statistical data for Israel are supplied by and under the responsibility of the relevant Israeli authorities. The use of such data by the OECD is without prejudice to the status of the Golan Heights, East Jerusalem and Israeli settlements in the West Bank under the terms of international law.

\section{(c) OECD (2017)}

You can copy, download or print OECD content for your own use, and you can include excerpts from OECD publications, databases and multimedia products in your own documents, presentations, blogs, websites and teaching materials, provided that suitable acknowledgment of OECD as source and copyright owner is given. All requests for commercial use and translation rights should be submitted to rights@oecd.org 
ECO/WKP(2017)53

\section{ABSTRACT/RÉSUMÉ \\ Corporate governance and firm performance in China}

A key priority in China's "new normal" period -- where returns on investment are slackening -- is corporate governance, which could lead to enhanced productivity by a better management of resources at the firm level. Corporate governance principles for listed firms follow global best practices, though their history is relatively short and the Chinese stock market has a number of features that make the investigation of the impact of various corporate governance practices on firm performance of particular interest. Productivity is considered as a major measure of firm performance, but for comparison accounting indicators are also used to check the impact of selected corporate governance practices using firm-level data of listed firms between 1999 and 2015. The results are broadly in line with the existing literature: once controlling for endogeneity, there is no evidence that a greater share of independent directors boosts firm performance in general. At the time when the requirement that at least one third of directors must be independent was introduced in 2002, however, profitability improved. A greater salary gap between executives and staff hurts productivity, but boosts ROA and ROE, which are often among the objectives of executives and thus encourage them to seek short-term returns, even at the expense of productivity. While volume-based growth may lead to higher performance by the accounting ratios, it does not necessarily guarantee higher productivity. If such an expansion is debt financed, it can even harm productivity. Excessive ownership concentration appears harmful, but a certain degree of concentration may improve performance. Institutional investors, even though may own only a tiny fraction of shares, are found to boost firm performance.

This Working Paper relates to the 2017 OECD Economic Survey of China (www.oecd.org/eco/surveys/economic-survey-china.htm).

Keywords: China, corporate governance, productivity, independent directors, board structure, executive compensation, ownership concentration, institutional investors

$$
\text { JEL: G34, G38, P31 }
$$

$$
* * * * * * * * * * * * *
$$

\section{Gouvernance d'entreprise et performance des entreprises en Chine}

La gouvernance d'entreprise est l'une des principales priorités de la Chine au cours de la période de « nouvelle normalité », durant laquelle les rendements sur investissement fléchissent. Une bonne gouvernance d'entreprise peut permettre d'accroître la productivité grâce à une meilleure gestion des ressources de l'entreprise. Bien que relativement récents, les principes de gouvernance d'entreprise applicables aux sociétés cotées en bourse sont conformes aux meilleures pratiques internationales, même si le marché boursier chinois présente un certain nombre de caractéristiques qui justifient d'examiner attentivement l'impact de diverses pratiques de gouvernance sur les performances des entreprises. La productivité est considérée comme étant un indicateur essentiel de la performance, mais des mesures comptables sont également utilisées à des fins comparatives pour vérifier les effets d'une sélection de pratiques de gouvernance d'entreprise en employant des données relatives à des sociétés cotées en bourse entre 1999 et 2015. Les résultats recoupent pour l'essentiel les études existantes : une fois l'endogénéité prise en compte, rien ne prouve qu'un nombre plus élevé d'administrateurs indépendants améliore les performances d'une entreprise en général. Néanmoins, lorsque l'obligation d'indépendance d'au moins un tiers des administrateurs a été mise en place en 2002, la rentabilité s'est accrue. Un écart de salaire plus important entre cadres dirigeants et subordonnés pénalise la productivité, mais conduit à une augmentation du rendement des actifs et des capitaux propres, qui fait souvent partie des objectifs des cadres et les encourage à rechercher un rendement à court terme, fût-ce aux dépens de la productivité. Si, mesurée selon les ratios comptables, la croissance en volume peut améliorer les performances, elle ne garantit pas nécessairement des gains de productivité. Si cette expansion est financée par recours à l'endettement, elle peut même nuire à la productivité. Une concentration excessive de l'actionnariat semble dommageable, mais un certain degré de concentration peut améliorer les résultats. La présence d'investisseurs institutionnels, même lorsqu'ils ne détiennent qu'une fraction minime du capital, est favorable aux performances d'une entreprise.

Ce document de travail est associé à l'Étude économique de la Chine 2017 (http://www.oecd.org/fr/eco/etudes/etude-economique-chine.htm).

Mots clés : Chine, gouvernance d'entreprise, productivité, administrateurs indépendants, structure du conseil, rémunération des cadres, concentration de l'actionnariat, investisseurs institutionnels

JEL: G34, G38, P31 


\section{TABLE OF CONTENTS}

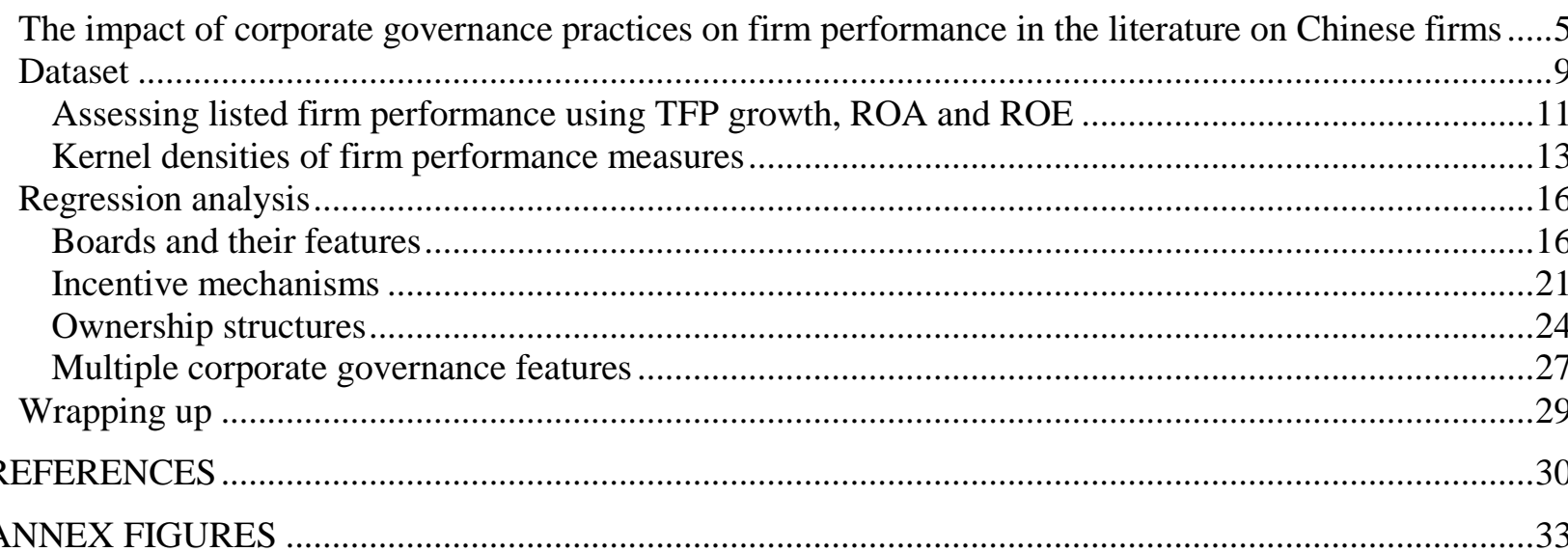

\section{Tables}

Table 1. Summary of selected studies on the impact of corporate governance on firm performance in

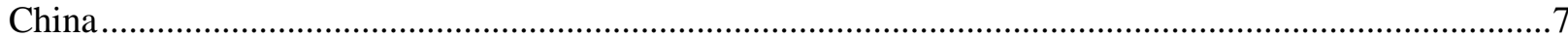

Table 2. Number of companies by listing board 1990-2015 ................................................................10

Table 3. Summary statistics of the variables used in the analysis ........................................................11

Table 4. The share of independent directors and firm performance by OLS with fixed effects................18

Table 5. The share of independent directors and firm performance by DID and GMM ........................20

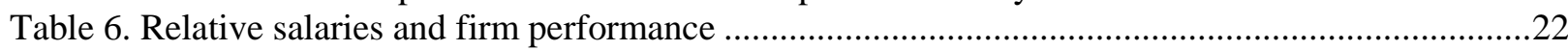

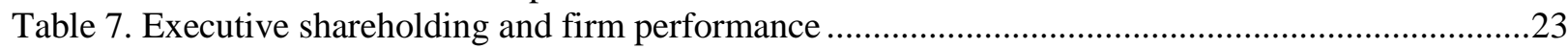

Table 8. Shareholding by the largest shareholder and firm performance ............................................25

Table 9. Shareholding by the ten largest shareholders and firm performance ..........................................26

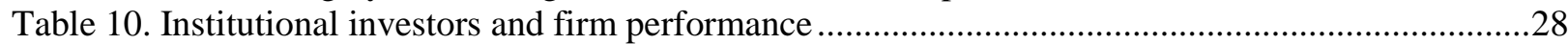

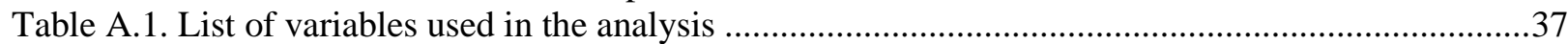

\section{Figures}

Figure 1. Listed firm performance by size, age, listing history, sector and ownership ...........................13

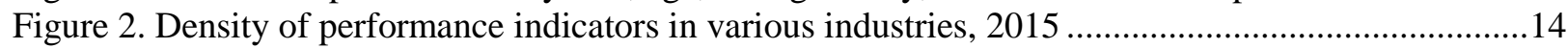

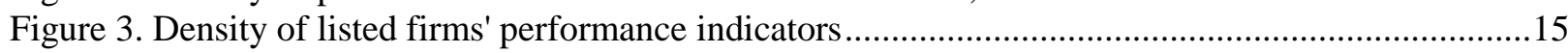

Figure 4. Listed firms in China have a board of directors and a supervisory board ...............................17

Figure A.1. Listed firm performance by size, age, listing history, sector and ownership.........................33

Figure A.2. Listed firm performance by size, age, listing history and ownership ...................................34

Figure A.3. Listed firm performance by size, age, listing history, sector and ownership.........................35

Figure A.4. Evolution of productivity of listed firms by size, age, listing history, sector and ownership.36 
ECO/WKP(2017)53

\title{
CORPORATE GOVERNANCE AND FIRM PERFORMANCE IN CHINA
}

\author{
By Margit Molnar, Wenhao Chen and Baolin Wang ${ }^{1}$
}

\section{Corporate governance is gaining prominence as a way to improve performance amid slowing growth}

As China's growth slows, increasing emphasis is being put on finding ways to enhance efficiency and improve firm performance. Beyond the immediate need to reduce corporate debt, which is estimated to hover around $170 \%$ of GDP, a series of measures are also needed to boost medium- to longer-term firm performance. One key priority in that respect is to improve corporate governance, which could lead to enhanced productivity by a better management of resources at firm level.

Adequate and effective corporate governance is indispensable to deliver long-term value to shareholders and other stakeholders. It also builds confidence in capital markets and enhances trust in business transactions. Furthermore, good corporate governance encourages socially and environmentally responsible behaviour on the part of firms and makes it easier for foreign firms to operate in China.

Although the quality of governance is important for firms of all types and sizes, in China corporate governance is mainly discussed in the framework of listed firms and state-owned enterprises (SOEs). China's Corporate Governance Code, which was adopted in 2002 (using the OECD Principles of Corporate Governance as a reference) applies only to listed firms, but SOEs have a different set of corporate governance principles. However, no corporate governance laws/rules exist for non-listed non-state firms (with the exception of the few aspects in the Company Law), which, for instance, are not required to set up a board.

Against this backdrop, and also for reasons of data accessibility, this paper focuses on the corporate governance practices of listed firms in China, examining how they affect firm performance. It starts with a brief literature review, before turning to the empirical analysis. The performance of the firms included in a 1999-2015 dataset is described using accounting indicators as well as firm-level productivity. Then regressions are run on the same annual dataset to assess the impact of various features of the boards, incentive mechanisms and ownership structure.

\section{The impact of corporate governance practices on firm performance in the literature on Chinese firms}

Corporate governance can be viewed as a mix of tools to ensure financiers of the company that they get a fair return on their investment (Shleifer and Vishny, 1997). Effective corporate governance is indispensable to deliver long-term value to shareholders. Traditionally, corporate governance mechanisms attempt to address the basic agency problem within the firm that relates to the separation of ownership and control. More recently, however, controlling owners are more common in listed firms than dispersed ownership, which raises new types of issues (Isaksson and Çelik, 2013). While controlling shareholders could potentially solve the agency problem between shareholders and managers, they often expropriate minority shareholders. Thus, in this setting, a major issue is how to avoid tunnelling or other abusive related party transactions. Corporate governance practices also cover incentive mechanisms to motivate management and other means to boost efficiency. Thus, the theoretical link between corporate governance and firm performance is straightforward, but it is a matter of empirical investigation to decide how various corporate governance mechanisms actually work in practice. Numerous studies have been published on

\footnotetext{
${ }^{1}$ Margit Molnar heads the China Desk in the OECD Economics Department, Wenhao Chen was a temporary staff and Baolin Wang a secondee from the National Development and Reform Commission at the China Desk when preparing this paper. The authors would like to thank Alvaro Pereira, Robert Ford, Ben Westmore of the OECD's Economics Department and Serdar Çelik, Alejandra Medina, Adriana de la Cruz, Yun Tang and Inga van den Bongard of the Directorate for Financial and Enterprise Affairs as well as Chinese government officials for valuable comments on earlier drafts. Special thanks go to Hyunjeong Hwang for statistical support and Sisse Nielsen, Mercedes Burgos and Laura Dockings for editorial assistance.
} 
various aspects of corporate governance. Here a selection of recent ones (some of which are based on fairly old data, however) is reviewed, chosen for their relevance to the empirical analyses in this paper (Table 1).

The board of directors is a key corporate governance mechanism that mitigates the agency problem between management and shareholders (Jensen and Meckling, 1976) in the traditional setting or monitors controlling shareholders or dominant owners. In China, it is the independent directors whose major task is to monitor controlling shareholders. That is why they are not only barred from any position in the company, but they also have to be independent from majority shareholders. The board hires and fires CEOs and assesses their performance. In addition, the board also performs an advisory role, whose importance may depend on market structure and access to finance, among other things. There is no compelling empirical evidence as to whether boards should be big or small: large boards may be better at drawing on a broader palette of expertise, and small ones may be better at monitoring. Large boards have the potential to bring in resources but can also reduce firm performance due to coordination and accountability problems.

Using return on assets (ROA) as a performance indicator, Chen (2015) finds that listed firms with larger boards perform better. A major novelty of his work is establishing a relationship between institutional factors and corporate governance characteristics. A weak helping hand from the government is associated with a larger board size, where helping hand is measured by the senior manager's answer to the question: what percentage of government officials that your firm regularly interacts with are oriented toward helping, rather than hindering, your activity? By contrast, Liu et al. (2015) find that smaller board size is associated with better firm performance, based on return on equity (ROE). Besides the two different measures of firm performance, the studies use different datasets: Chen (2015) uses a World Bank dataset of 2400 firms (including both public and privately-held) in 2003, while Liu et al. (2015) use the Chinese Securities Market and Accounting Research (CSMAR) Database of 2057 listed non-financial, non-utility firms over 1999-2012. Huang and Wang (2015) examine the impact of board size on risk taking (measured by the variability of monthly stock returns and of cash flows) and confirm that smaller boards tend to adopt riskier policies, though they are more conservative in using debt financing.

The board structure can be viewed as the result of balancing the costs and benefits of having independent directors. Major benefits such as better monitoring and accessing a greater pool of resources, including information, need to be weighed against costs. In addition to wage costs, communication and coordination costs may also be significant with the increase of the number of independent directors. Moreover, such costs and benefits can be sector or even firm specific. Hence, the board structure is endogenously determined taking into account the firm's contracting and operating environments (Linck et al. 2008 and Wintoki et al. 2012). Thus, in an empirical investigation of the impact of the board structure on performance, endogeneity, simultaneity and unobserved heterogeneity need to be taken into account. Owing to such interactions between the board structure and firm performance, empirical analysis using US data does not provide clear evidence of a causal relationship between board composition and performance. This is not the case for other countries, where often a positive relationship is found. Chen (2015) finds that boards with more outsiders perform better; moreover a weak helping hand from the government exerts positive effects on both the number and the share of outsiders on the board. Liu et al. (2015) show that independent directors have an overall positive effect on firm performance in China. Moreover, the positive relationship between board independence and firm performance is stronger in government-controlled firms and in firms with lower information acquisition costs.

Li et al. (2015) show that the positive effect of board independence on firm performance strengthens as ownership concentration declines. This finding, however, only holds in the case of privately-owned firms, not for state-owned ones (no matter whether centrally or locally controlled). Zhu et al. (2016) examine the ranking of board directors and show that empowered independent directors enhance firm value. More specifically, while independent directors generally follow management in voting, those who rank higher more often vote against the management. 
Table 1. Summary of selected studies on the impact of corporate governance on firm performance in China

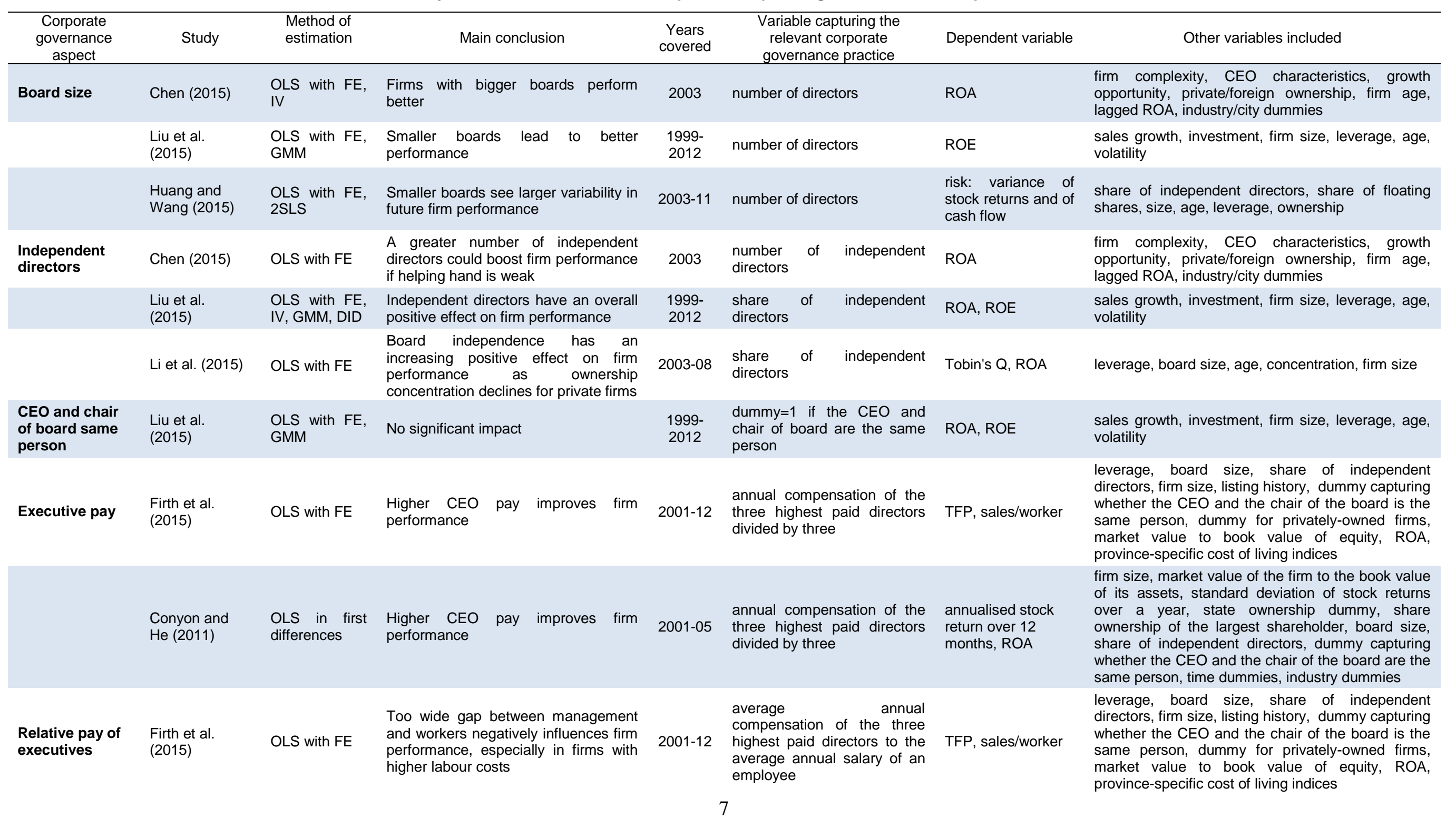


ECO/WKP(2017)53

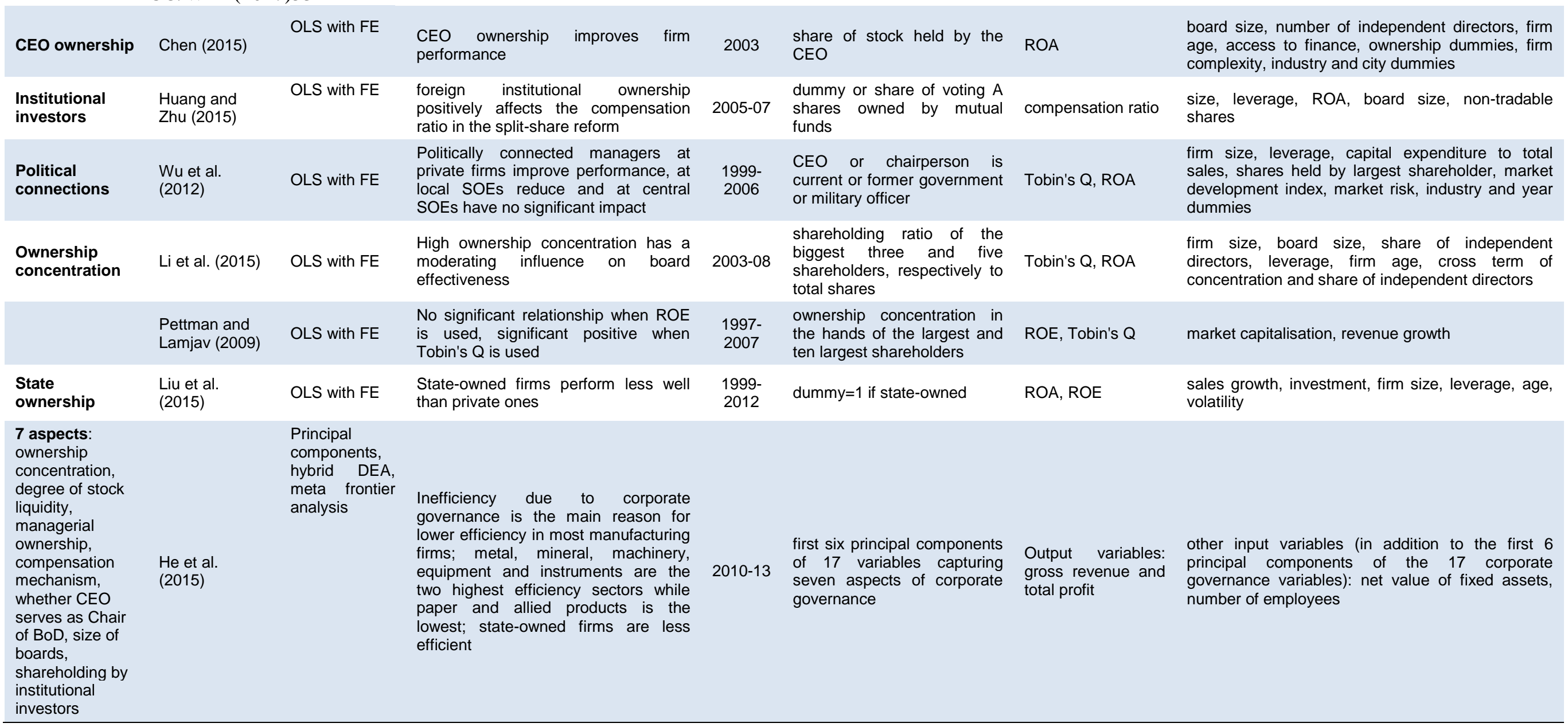

Note: OLS with FE stands for OLS with fixed effects, IV for instrumental variables, GMM for generalised method of moments, DiD for difference-in-differences, DEA for data envelopment analysis and 2SLS for 2-stage least square.

Source: Authors' compilation. 
In China, political connections are considered a prerequisite to succeed in business. Wu et al. (2012) look at whether political connections affect firm performance. They define political connection as a CEO or chairperson who is or was a government or military officer and found that politically connected private firms perform better, while such connections at local SOEs result in inferior performance. Political connections at central SOEs have no significant impact on firm performance.

Remuneration of executives is another important aspect of corporate governance. Compensation packages are set in a way to solve moral hazard problems in a setting with risk- and effort-averse agents and riskneutral principals. The principal-agent model predicts that executive pay is positively related to firm performance. In China, it could be more relevant to look at the salary gap between managers and workers as inequalities are increasing and are raising concerns. The theoretical literature is inconclusive regarding the impact of the salary gap between managers and workers. On the one hand, a large gap may strengthen the feeling of unfairness and demotivate workers, leading to lower efforts and efficiency. On the other hand, a higher wage gap may be a carrot for workers to work harder with the prospect of a higher future wage (Clark et al., 2009). Tournament theory also supports high wage disparity as it encourages healthy competition (Main et al., 1993).

Firth et al. (2015) use World Bank microdata over 2001-12 and show that a large wage gap between managers and workers (using the ratio of manager pay to average worker's pay) is negatively associated with high productivity, even though high executive compensation is positively related to firm performance. Conyon and $\mathrm{He}$ (2011) also find that executive compensation is positively related to firm performance using listed company data over 2001-05. The variables capturing firm performance differ in the two studies: Firth et al. (2015) use TFP, while Conyon and He (2011) use ROA and the annualised stock return over twelve months. Compensation can be cash or shares/stock options. Share ownership by managers provides direct financial incentives to increase shareholder value (Murphy 1999 and Conyon and Murphy, 2000).

Institutional investors can be important external monitors and thereby help reduce the risk of expropriation of minority shareholders by controlling ones. In China, foreign mutual funds are found to be more effective in that regard, as local mutual funds appear to yield to political pressure (Firth et al., 2010). Huang and Zhu (2015) show that foreign institutional investors are less prone to political pressure and that they are more likely to perform arm's-length monitoring.

\section{Dataset}

The Chinese Securities Market and Accounting Research (CSMAR) Database of listed firms is used for the analysis in this paper. It is a comprehensive dataset of listed firms including both financial variables and rich information on corporate governance practices. Missing financial and other variables were filled in from the Bloomberg financial database and individual company reports when available.

The estimation uses an unbalanced panel of listed firms in the Main Board of the Shanghai and Shenzhen Stock Exchange, the Small and Medium-size Enterprise Board (SME Board), and the Growth Enterprise Board of the Shenzhen Stock Exchange. As of end-2015, more than half of listed firms were listed on the main boards in Shanghai and Shenzhen, over a quarter on the SME Board in Shenzhen and less than a fifth on the Growth Enterprise Board in Shenzhen (Table 2). Although the dataset is available from 1990 onwards, the analysis is based on data between 1999 and 2015 as total factor productivity (TFP), a major variable of interest, could not be estimated for the earlier period. 
Table 2. Number of companies by listing board 1990-2015

\begin{tabular}{|c|c|c|c|c|}
\hline Year & Main Board & $\begin{array}{c}\text { Small and } \\
\text { Medium-size } \\
\text { Enterprise Board }\end{array}$ & $\begin{array}{c}\text { Growth } \\
\text { Enterprise Board }\end{array}$ & Total \\
\hline 1990 & 9 & 0 & 0 & 9 \\
\hline 1991 & 13 & 0 & 0 & 13 \\
\hline 1992 & 54 & 0 & 0 & 54 \\
\hline 1993 & 180 & 0 & 0 & 180 \\
\hline 1994 & 194 & 0 & 0 & 194 \\
\hline 1995 & 312 & 0 & 0 & 312 \\
\hline 1996 & 519 & 0 & 0 & 519 \\
\hline 1997 & 723 & 0 & 0 & 723 \\
\hline 1998 & 824 & 0 & 0 & 824 \\
\hline 1999 & 894 & 0 & 0 & 894 \\
\hline 2000 & 1026 & 0 & 0 & 1026 \\
\hline 2001 & 1098 & 0 & 0 & 1098 \\
\hline 2002 & 1155 & 0 & 0 & 1155 \\
\hline 2003 & 1208 & 0 & 0 & 1208 \\
\hline 2004 & 1253 & 39 & 0 & 1292 \\
\hline 2005 & 1220 & 50 & 0 & 1270 \\
\hline 2006 & 1221 & 119 & 0 & 1340 \\
\hline 2007 & 1234 & 220 & 0 & 1454 \\
\hline 2008 & 1235 & 270 & 0 & 1505 \\
\hline 2009 & 1236 & 356 & 58 & 1650 \\
\hline 2010 & 1268 & 552 & 188 & 2008 \\
\hline 2011 & 1308 & 650 & 292 & 2250 \\
\hline 2012 & 1343 & 697 & 355 & 2395 \\
\hline 2013 & 1365 & 714 & 379 & 2458 \\
\hline 2014 & 1414 & 734 & 419 & 2567 \\
\hline 2015 & 1480 & 776 & 497 & 2753 \\
\hline
\end{tabular}

Source: Chinese Securities Market and Accounting Research (CSMAR) database.

Financial firms are excluded from the analysis owing to their unique asset structure and regulatory oversight. Firms with negative assets, no employees or other irregular values, such as for instance TFP growth above 500\% or annual executive compensation below CNY 50000 are also excluded. Here extreme outlier is the main criterion for exclusion from the sample used for the analysis instead of unselective truncation as done in several studies. The deletion of $1 \%$ of the sample for each of the tails of the distribution would have unreasonably reduced the sample size by breaking up the time series, thereby reducing the scope for taking into account the underlying dynamics in the data.

Existing literature mostly uses market-based (Tobin's Q) or accounting-based measures of performance (ROA and ROE). There are also a few papers that use productivity. Here accounting (ROA and ROE) measures as well as TFP are used to proxy firm performance. Market value is not used as stock market valuation does not necessarily reflect firm performance (Allen et al., 2005). TFP reflects the firm's ability to combine its resources efficiently, and is therefore a highly relevant measure of performance. It is, however, not readily available, and needs to be estimated from a production function. TFP is the residual once capital, labour and intermediate inputs have been accounted for. TFP is estimated by OLS with fixed effects. As fixed effects can only partly account for the endogeneity of inputs, the Olley and Pakes (1996) method is also used, which corrects for this problem. In the event, the estimates obtained through OLS 
with fixed effects and the Olley and Pakes method are very close, indicating that fixed effects largely control for endogeneity.

Basic statistics for the major variables of interest (the definition of the variables is provided in Annex Table A.1) indicate that some corporate governance variables display little cross-sectional variation (Table 3). For instance, the share of independent directors is around one third, as required by the law and the board size of 8-9 members is also quite standard. Shareholding by company executives is virtually nonexistent and institutional investors hold a small percentage of shares. There is greater variation in the financial variables, in particular in asset sizes sales growth.

Table 3. Summary statistics of the variables used in the analysis 2015

\begin{tabular}{|c|c|c|c|c|c|c|}
\hline & Mean & $\begin{array}{l}\text { Standard } \\
\text { deviation }\end{array}$ & $\begin{array}{c}\text { 25th } \\
\text { percentile }\end{array}$ & Median & $\begin{array}{c}\text { 75th } \\
\text { percentile }\end{array}$ & $\begin{array}{c}\text { Number of } \\
\text { observations }\end{array}$ \\
\hline TFP estimated by Olley-Pakes & 0.714 & 0.274 & 0.628 & 0.706 & 0.809 & 2412 \\
\hline $\begin{array}{l}\text { TFP estimated by OLS with fixed } \\
\text { effects }\end{array}$ & 0.753 & 0.272 & 0.668 & 0.742 & 0.844 & 2412 \\
\hline ROA & 0.031 & 0.075 & 0.011 & 0.032 & 0.059 & 2412 \\
\hline ROE & 0.056 & 0.196 & 0.024 & 0.068 & 0.119 & 2412 \\
\hline Share of independent directors & 0.346 & 0.087 & 0.333 & 0.333 & 0.375 & 239 \\
\hline Board size (number of directors) & 9.113 & 1.961 & 8 & 9 & 9 & 23969 \\
\hline $\begin{array}{l}\text { Salary gap (average executive to } \\
\text { average worker salary) }\end{array}$ & 7.353 & 119.751 & 2.969 & 4.868 & 7.963 & 2392 \\
\hline Executive shareholding & 0.037 & 0.108 & 0 & 0 & 0.001 & 23001 \\
\hline Shares held by the largest shareholder & 0.369 & 0.158 & 0.244 & 0.348 & 0.486 & 22081 \\
\hline $\begin{array}{c}\text { Shares held by the ten largest } \\
\text { shareholders }\end{array}$ & 0.572 & 0.156 & 0.465 & 0.583 & 0.689 & 22081 \\
\hline Shares held by institutional investors & 0.049 & 0.072 & 0.004 & 0.019 & 0.064 & 18045 \\
\hline Leverage & 0.466 & 0.206 & 0.311 & 0.473 & 0.622 & 24117 \\
\hline Investment ratio & 0.059 & 0.059 & 0.017 & 0.042 & 0.082 & 24100 \\
\hline Sales growth & 0.053 & 0.478 & -0.117 & 0.081 & 0.213 & 20635 \\
\hline Assets (in billion CNY) & 9.09 & 52.60 & 1.12 & 2.26 & 5.08 & 24117 \\
\hline Age (years) & 13.662 & 5.346 & 10 & 13 & 17 & 24117 \\
\hline
\end{tabular}

Source: Authors' compilation based on the CSMAR database.

\section{Assessing listed firm performance using TFP growth, ROA and ROE}

Firm performance varies widely depending on size, age, listing history, sector and ownership (Figure 1). Productivity trends observed in listed-company micro data broadly reflect those at the macro level, with 
very low productivity growth in recent years. Medium, small and micro-enterprises (between 50 and 249, 20 and 49 and below 20 employees, respectively) experienced negative productivity growth over 2014-15 and large and very large firms (with over 250 employees) no growth (Panel A). ROA and ROE are the highest for micro-firms, likely because most listed micro-firms are start-ups on the Growth Enterprise Board that tend to generate higher returns. In the small firm category (20-49 employees), returns were negative, but for large and very large companies (above 250 employees) they stood at 3-4\% in terms of ROA and around $5 \%$ in terms of ROE.

Well-established firms, over 15 years old, had positive productivity growth, in contrast to all the other categories (Panel B). Moreover, productivity fell most for the youngest firms established within the past five years. Accounting measures, however, show that the younger a firm, the higher the return on its assets or equity. This observation is also valid for the other years examined: 2010, 2005 and 2000 (Annex Figures A1-3). Time series data also indicate that older firms increased their productivity more rapidly (Annex Figure A.4). Intuitively, TFP performance should be positively correlated to ROA and ROE, but in this sample they often display the opposite correlation. This may be because in many firms ROA or ROE serve as a performance target and the base for evaluation of executive performance. In contrast, TFP or any productivity measure does not seem to appear among company objectives. This may encourage executives to seek short-term returns, even at the expense of long-term productivity.

Recently listed companies have negative productivity growth, but the highest return on assets and equity (Panel C). Productivity growth was the highest for firms that have been listed for 10-15 years at around 1\% and was also positive for firms that have been listed for over 15 years.

Productivity of commercial companies grew the fastest, followed by the property sector (which includes construction according to the China Securities Regulatory Commission's industry classification), while it fell in the case of utilities, industrial (which include manufacturing and mining) and other firms (Panel D). Commercial firms include a range of services, which have been developing fast as the economy is rebalancing from manufacturing to services. Utilities have the highest returns, partly reflecting enduring price controls in many industries. Conglomerates performed the worst on all measures (this is a hybrid group including industries that cannot be categorised into utilities, property, industry or commercial services, such as for instance, agricultural firms, as well as firms that earn less than half of their revenue from their main business).

In 2015, foreign firms performed best on all measures followed by private domestic firms, SOEs managed by government agencies, central SOEs (SOEs under SASAC or managed by the Ministry of Finance) and local SOEs (Panel E). Notwithstanding the slowing of the economy, which squeezed enterprise profits, foreign firms managed to get a return of $5 \%$ on their assets and nearly $9 \%$ on their equity. This may be explained by their productivity performance, which was above that in other ownership categories. Private domestic firms' performance comes second after foreign firms in terms of return on assets and equity, but was the second lowest on the measure of productivity growth. This category includes purely privately owned firms as well as firms with non-controlling State shareholding. SOEs under various central government ministries and agencies ranked third on ROA and ROE and second on the productivity growth measure. Central SOEs are the listed subsidiaries of the roughly 100 enterprise groups managed by SASAC and the groups controlled by the Ministry of Finance (among which there are about 100 culturerelated enterprise groups). This group did not manage to improve its productivity in 2015, notwithstanding progress with SOE reform at group level. Local SOEs managed by SASACs at the province or prefecture level performed the worst in terms of productivity, while on the other two measures they were on par with central SOEs. Firm performance by ownership varies widely across years (Annex Figures A.1-4).

In 2015, privately-owned companies in general (Panel F), be it domestic or foreign, perform better than SOEs defined as firms controlled by the State, either in absolute or relative sense (here SOEs include all three categories of central, local and agency-controlled SOEs). 
ECO/WKP(2017)53

Figure 1. Listed firm performance by size, age, listing history, sector and ownership Performance measured by TFP growth, ROA and ROE, 2015
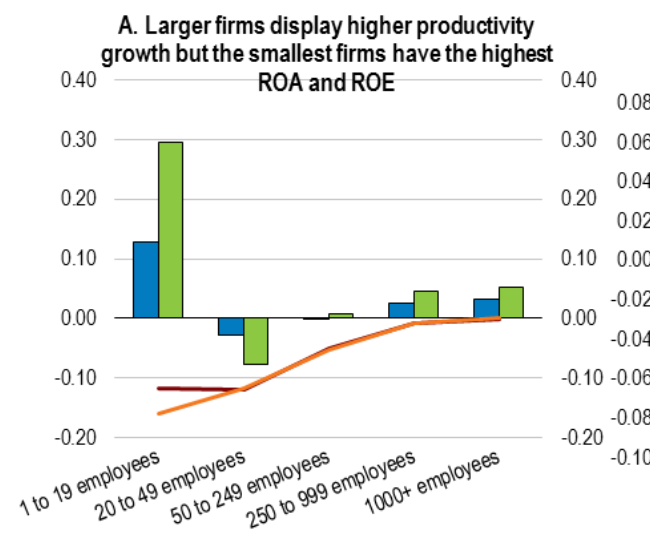

B. Younger companies have higher ROA and ROE, but lower productivity growth
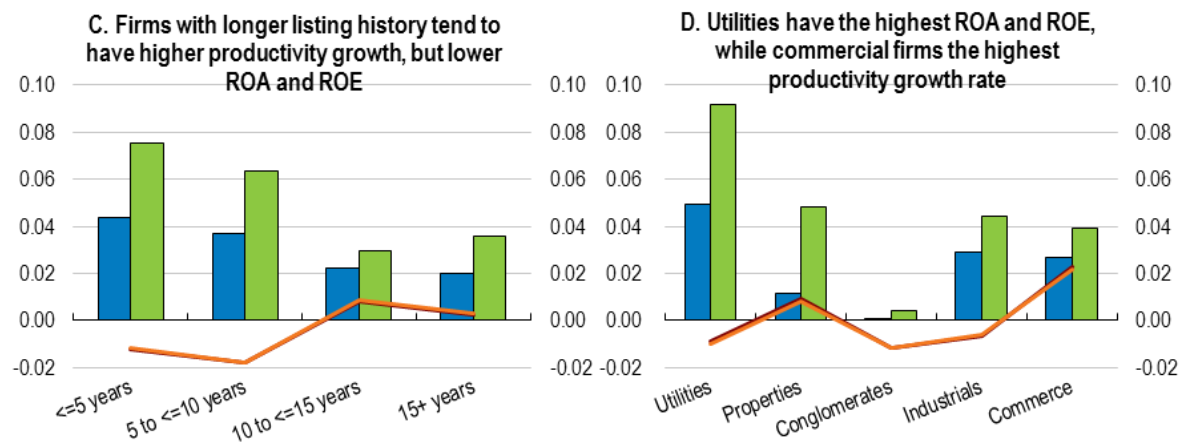

E. Foreign firms perform best on all measures

F. Non-SOEs perform better
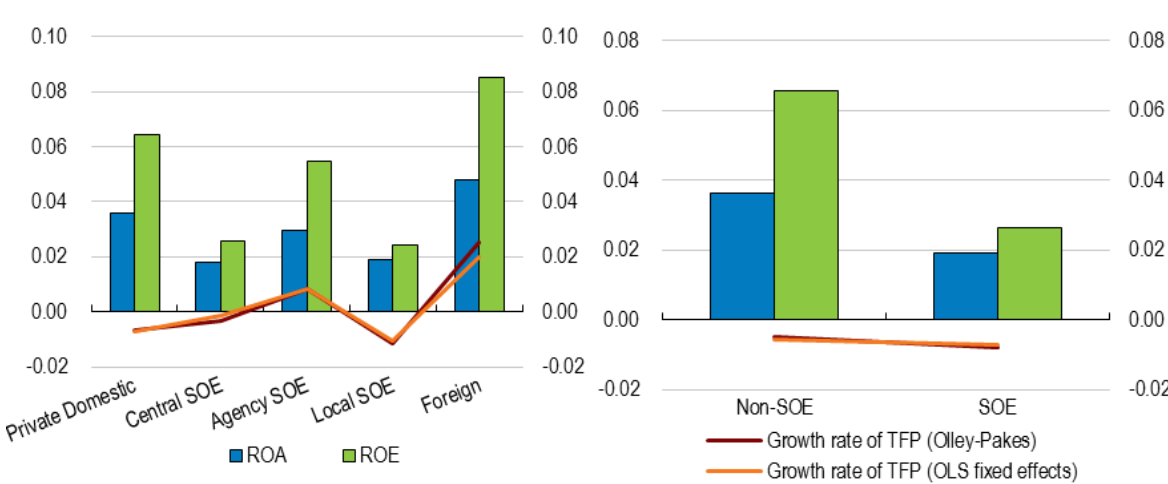

Note: ROA is net income divided by total assets, ROE is net income divided by shareholders' equity, TFP (Olley-Pakes) is TFP estimated by the Olley-Pakes method taking into account endogeneity, TFP (OLS fixed effects) is TFP estimated using OLS with fixed effects and thus partially accounting for endogeneity. In Panel D, conglomerates refer (i) either to firms in sectors that do not belong to utilities, property, industrials or commerce or (ii) to firms where the main activity produced less than half of revenues. In Panel E, central SOEs refer to SOEs managed by SASAC and the Ministry of Finance, agency SOEs to SOEs under government agencies and local SOEs managed by local SASACs. In Panel F, State-owned refers to state-controlled firms, including with absolute majority ownership and without absolute majority ownership but relative control power by the State.

Source: Authors' calculation based on the CSMAR database.

\section{Kernel densities of firm performance measures}

Density estimates provide an additional insight into the distribution of firm performance indicators. For density, the kernel method was used, which estimates density of the underlying data without making any parametric assumptions about the underlying distribution. While density estimates confirm what simple bar charts show in the various dimensions, they also show the shape of the distribution of those indicators 
(Figure 2). The distribution of utilities' or property enterprises' TFP growth, for instance, has a somewhat longer and fatter tail, indicating that a large share of those firms increased their productivity more than firms in other industries (Panels C and D). The left-hand side tails are also thicker for those categories, showing a large share of firms with falling productivity, too. Commercial and industrial firms have thin tails on both sides; most of those firms' productivity growth is hovering around zero. Not just the averages, but also the distribution of the TFP growth estimates obtained by OLS with fixed effects and the Olley and Pakes method are very similar.

Figure 2. Density of performance indicators in various industries, 2015

A. ROA by industry

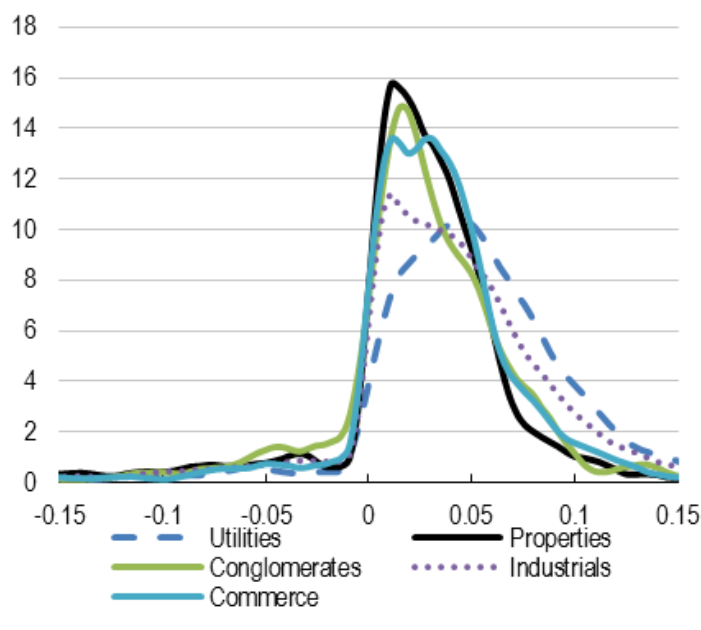

C. TFP(Olley-Pakes) by industry

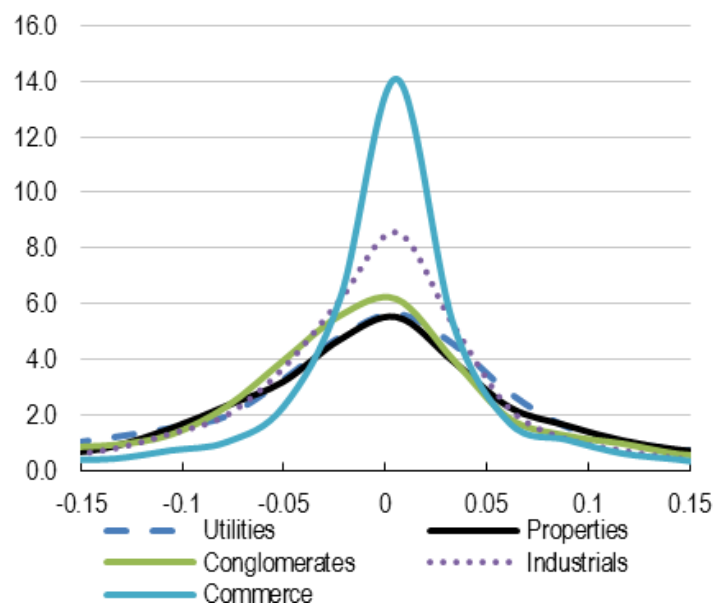

\section{B. ROE by industry}

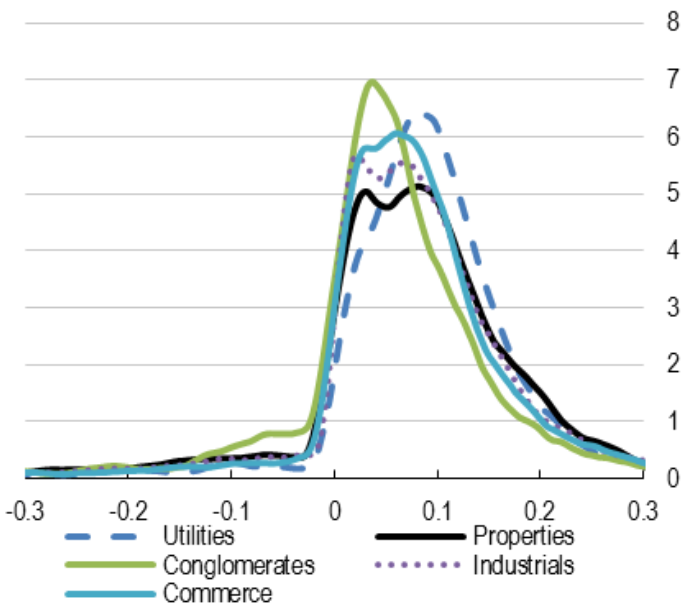

D. TFP (OLS fixed effects) by industry

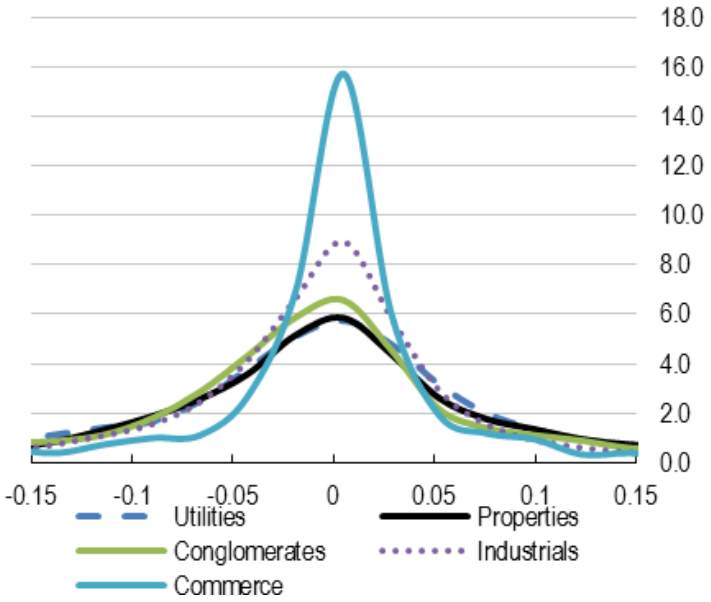

Note: The densities are using a Gaussian kernel function. ROA is net income divided by total assets, ROE is net income divided by shareholders' equity, TFP (Olley-Pakes) is TFP estimated by the Olley-Pakes method taking into account endogeneity, TFP (OLS fixed effects) is TFP estimated using OLS with fixed effects and thus partially accounting for endogeneity. Conglomerates refer (i) either to firms in sectors that do not belong to utilities, property, industrials or commerce or (ii) to firms where the main activity produced less than half of revenues. Properties include construction firms according to the China Securities Regulatory Commission's industry classification and industrials comprise manufacturing and mining firms.

Source: Authors' calculation based on the CSMAR database.

In terms of ROA, utilities clearly perform better, with a fat tail on the right side and a very thin one on the left (Panel A). Industrial firms have similarly a fat right-side tail, though this sector also includes many firms that are not able to boost their productivity, indicated by the highest density point being near zero. By ROE, property firms outperform utilities (Panel B), likely owing to their higher level of indebtedness and thus lower equity. 
The distribution of productivity growth estimates by firm ownership reveals that foreign firms have the highest density of rising productivity firms, though they also have a large share with falling productivity (Figure 3, Panel C and D). The high productivity performance of private firms, on average, can be explained by a few firms with very high productivity growth. Agency-controlled SOEs have no comparable "champions" but a large share of firms with falling productivity, which can explain their mediocre performance. Superior performance of foreign firms is confirmed by the ROA and ROE indicators (Panels A and B).

Figure 3. Density of listed firms' performance indicators

Kernel density

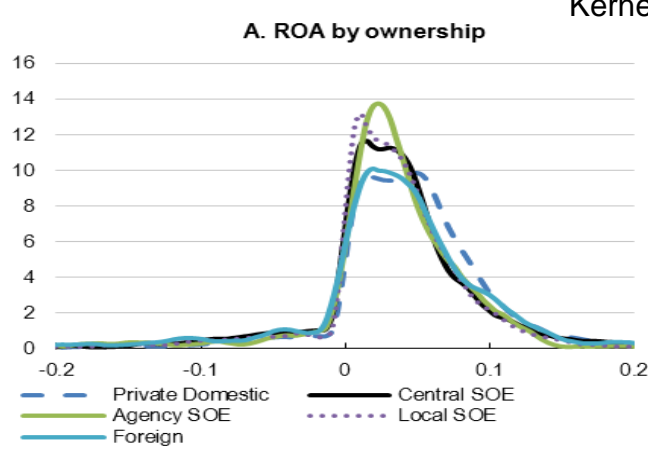

C. TFP (Olley-Pakes) by ownership
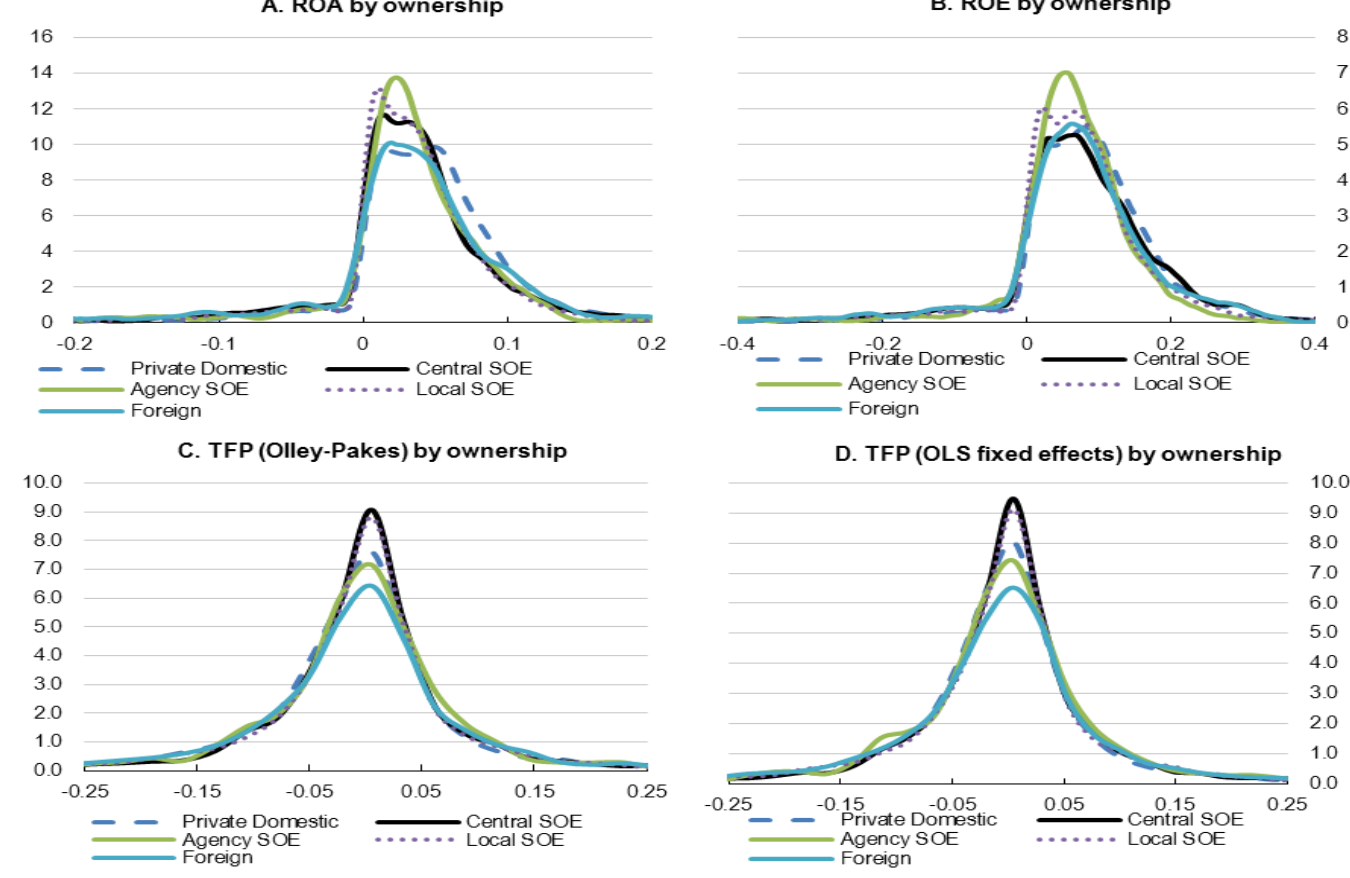

D. TFP (OLS fixed effects) by ownership

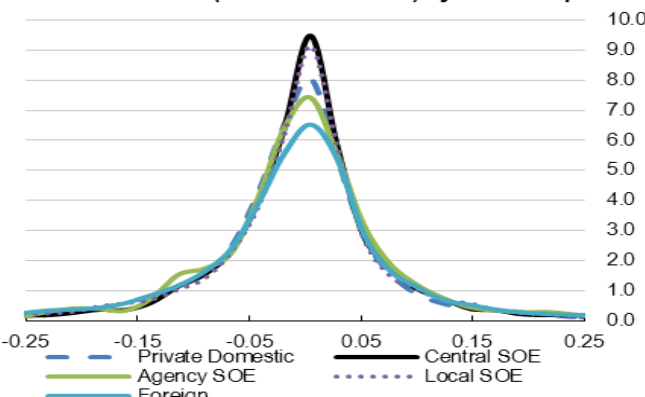

E. ROA by SOE and non-SOE

F. ROE by SOE and non-SOE
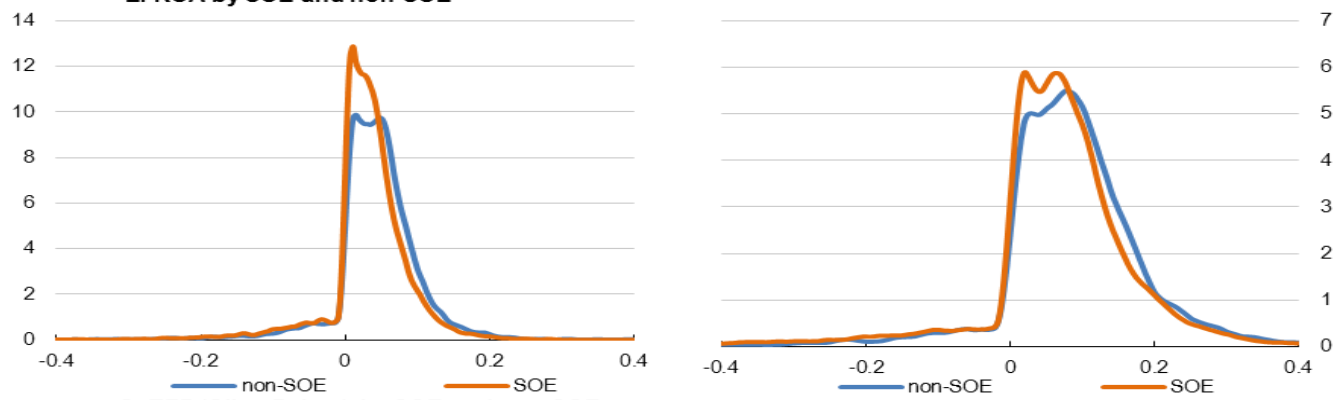

G. TFP (Olley-Pakes) by SOE and non-SOE

H. TFP (OLS fixed effects) by SOE and non-
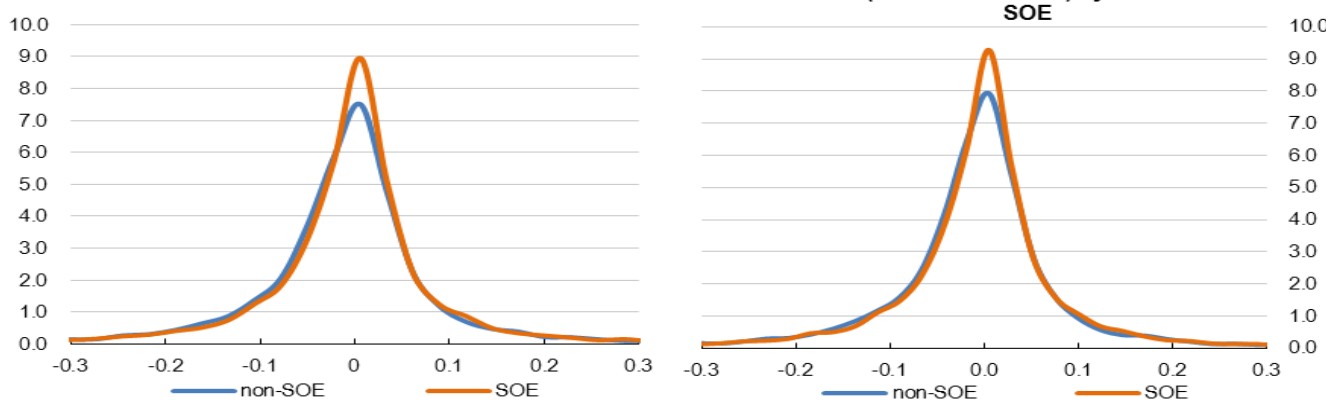

Note: The densities are using a Gaussian kernel function. ROA is net income divided by total assets, ROE is net income divided by shareholders' equity, TFP (Olley-Pakes) is TFP estimated by the Olley-Pakes method taking into account endogeneity, TFP (OLS fixed effects) is TFP estimated using OLS with fixed effects and thus partially accounting for endogeneity.

Source: Authors' calculation based on the CSMAR database. 
When comparing SOEs with non-SOEs, the ROA and ROE measures clearly indicate superiority of nonSOEs, though this differential is less pronounced when comparing productivity growth rates (Panels E, F, $\mathrm{G}$ and $\mathrm{H})$.

\section{Regression analysis}

The following regression analysis focuses on three areas: (i) features of the board of directors, (ii) incentives mechanisms and (iii) ownership structures, in particular ownership concentration, institutional investors and private versus various forms of State ownership.

Regression analysis of the relationship between corporate governance practices and firm performance involves endogeneity, which can stem from reverse causality, unobserved heterogeneity or simultaneity. Firm performance can affect the choice of corporate governance practices, making for reverse causality. In the case of board structure and firm performance, unobserved heterogeneity might be a problem, i.e. capable CEOs may chose more independent directors and post better firm performance. The choice of board structure may be related to firm performance targets, giving rise to simultaneity. Due to those endogeneity issues, OLS estimation will be biased. Including fixed effects may partially address the problem as it controls for unobserved, time-invariant heterogeneities (such as firm or managerial quality), but it does not deal with time-variant heterogeneities, reverse causality or simultaneity. To fully address those issues, the analysis in this paper also relies on generalised method of moments (GMM) and difference-in-differences (DiD) estimates, in addition to those obtained by OLS with fixed effects.

\section{Boards and their features}

In China, all listed firms must have a board of directors as well as a board of supervisors attached to the general shareholder meeting (Figure 4). The 2006 Company Law stipulates that the shareholder meeting is the supreme power organ of the corporation and accordingly, it has substantial managerial clout (Zhang, 2012), which is often the board of directors' in other countries. This allows major shareholders to control the operation of the company through the shareholder meeting.

The board of directors and the board of supervisors are instrumental in protecting minority shareholder rights and mitigating the agency problem between shareholders and management. The Company Law defines the roles of the board of directors as executors of the operations-related decisions made by the shareholder meeting (Article 47). The size of the board of directors can range from 5 to 19 members. Since 2003 , one-third of the board members must be independent. The board of supervisors' job is to monitor the behaviour of the directors and executives/managers of the company on behalf of shareholders (Article 54 of the Company Law).

In China, given the high degree of State ownership of listed firms and high ownership concentration, the role of independent directors could potentially be important as they could provide additional monitoring. They are, however, often not truly independent (Molnar, 2017), and thus their potential benefits may also be limited. Therefore, whether it makes a difference to have more independent directors remains an empirical question.

\section{Estimation by OLS with fixed effects}

To investigate the impact of independent directors on firm performance, first the following equation is estimated:

$$
\text { Performance }_{i, t}=\alpha+\beta_{1} \text { independent }_{i, t}+\beta_{2} \text { control }_{i, t}+d_{i}+d_{t}+\varepsilon_{i, t}(1)
$$

Here and in all subsequent equations, firm performance is measured by ROA, ROE and TFP (using two estimators: OLS with fixed effects and the Olley-Pakes method). The proportion of independent directors 
on the board is the key variable of interest. The logarithm of the size of the board, measured as the number of board members is also included as board size is an important characteristic related to corporate governance in the firm. Throughout the regression analysis, "control" stands for a vector of firm-specific variables including leverage, sales growth, investment share in total assets, firm size (captured by the logarithm of total assets), and firm age (logarithm of the number of years since establishment); the dummies $d_{i}$ and $d_{t}$ denote firm and year fixed effects, respectively; and $\varepsilon_{i, t}$ is the error term. Time-varying covariates are lagged to reduce the simultaneity problem. Standard errors are adjusted for clustering at the firm level to control for potential serial correlation and heteroskedasticity.

\section{Figure 4. Listed firms in China have a board of directors and a supervisory board}

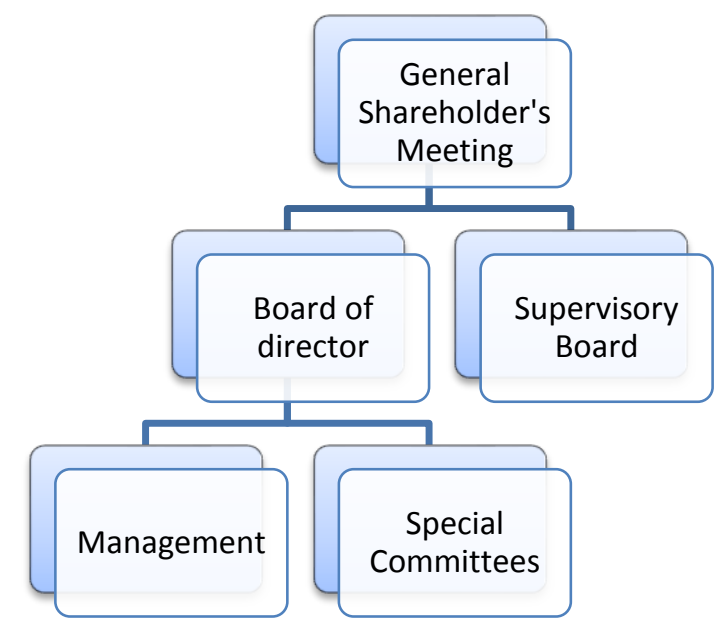

Source: Based on China's Code of Corporate Governance for listed firms.

The results of the estimation show that the higher the share of independent directors, the higher productivity, for both TFP estimates, and the level of significance of the coefficients is high at $1 \%$ (Table 4 columns 3 and 4). Using ROA or ROE as the measure of performance, the coefficients on the share of independent directors are still highly significant, though their size is half or smaller compared to the case where TFP is used as performance indicator (columns 1 and 2). This indicates that a greater share of independent directors is more conducive to both higher productivity and to higher returns. The greater coefficients in the case of TFP indicate that independent directors may have longer horizons and may be more concerned about longer-term issues, not just short-term performance.

The control variables also appear with the expected signs. In general, higher leverage is associated with weaker performance, as firms with higher leverage are likely to face higher interest rates and high interest payments draw away resources from more productive use. In the case of TFP measures used as performance indicators, the coefficient on the leverage ratio is highly significant and the size of the coefficient is large, indicating the productivity-reducing impact of high leverage. When using ROA as performance indicator, the coefficient is less significant and is smaller, while in the case of ROE it is not significant, showing that leverage does not have a comparable damaging effect on accounting indicators.

The ratio of investment to assets positively affects performance through the well-known productivityenhancing effect of investment. The results, however, indicate, that the coefficient on the investment ratio is significant only for one of the TFP equations (when it is estimated using OLS with fixed effects) and even in that case only at the $10 \%$ level and the coefficient is relatively small. This may indicate that firms in the sample already have relatively high investment ratios, so that the impact of additional investment on productivity is limited. In contrast, a higher investment ratio has a highly significant positive impact on accounting performance indicators. The impact of sales growth is not significant in the case of the TFP 
measures, indicating that volume-based growth does not necessarily mean higher productivity. Sales growth is, however, positively associated with accounting measures of performance. The size of the board does not appear to have a significant impact on firm performance. Younger firms perform better on all measures, while smaller firms (in terms of assets) only on accounting indicators.

Table 4. The share of independent directors and firm performance by OLS with fixed effects

\begin{tabular}{|c|c|c|c|c|}
\hline & ROA & ROE & $\begin{array}{l}\text { TFP (Olley- } \\
\text { Pakes) }\end{array}$ & $\begin{array}{c}\text { TFP (OLS with fixed } \\
\text { effects) }\end{array}$ \\
\hline & (1) & (2) & (3) & (4) \\
\hline \multirow[t]{2}{*}{ Share of independent directors } & $0.0311^{\star *}$ & $0.0827^{\star *}$ & $0.157^{\star \star *}$ & $0.156^{\star \star *}$ \\
\hline & $(0.0139)$ & $(0.0406)$ & $(0.0587)$ & $(0.0586)$ \\
\hline \multirow[t]{2}{*}{ Leverage ratio } & $-0.0116^{*}$ & -0.00185 & $-0.147^{* \star *}$ & $-0.156^{\star \star \star}$ \\
\hline & $(0.00648)$ & $(0.0270)$ & $(0.0271)$ & $(0.0270)$ \\
\hline \multirow[t]{2}{*}{ Investment ratio } & $0.0412^{* \star *}$ & $0.112^{\star *}$ & 0.0599 & $0.0964^{*}$ \\
\hline & $(0.0122)$ & $(0.0449)$ & $(0.0496)$ & $(0.0493)$ \\
\hline \multirow[t]{2}{*}{ Sales growth } & $0.00321^{\star *}$ & $0.00973^{* *}$ & 0.00400 & 0.00335 \\
\hline & $(0.00149)$ & $(0.00467)$ & $(0.00431)$ & $(0.00411)$ \\
\hline \multirow[t]{2}{*}{ Age (in logarithm) } & $-0.0346^{\star * *}$ & $-0.0822^{\star \star \star}$ & $-0.0876^{* * *}$ & $-0.0811^{\star *}$ \\
\hline & $(0.00774)$ & $(0.0212)$ & $(0.0328)$ & $(0.0321)$ \\
\hline \multirow[t]{2}{*}{ Total assets (in logarithm) } & $-0.00873^{\star * *}$ & $-0.0152^{\star \star}$ & -0.00186 & -0.00158 \\
\hline & $(0.00207)$ & $(0.00688)$ & $(0.00728)$ & $(0.00712)$ \\
\hline \multirow[t]{2}{*}{ Private ownership dummy } & 0.00520 & $0.0329^{\star *}$ & 0.0334 & 0.0324 \\
\hline & $(0.00673)$ & $(0.0156)$ & $(0.0309)$ & $(0.0302)$ \\
\hline \multirow[t]{2}{*}{ Central SOE dummy } & -0.00784 & -0.0195 & -0.0282 & -0.0263 \\
\hline & $(0.00789)$ & $(0.0230)$ & $(0.0336)$ & $(0.0329)$ \\
\hline \multirow[t]{2}{*}{ Agency-controlled SOE dummy } & -0.0112 & 0.00964 & -0.00106 & -0.000299 \\
\hline & $(0.0105)$ & $(0.0575)$ & $(0.0467)$ & $(0.0453)$ \\
\hline \multirow[t]{2}{*}{ Local SOE dummy } & -0.00495 & 0.00640 & -0.00936 & -0.00930 \\
\hline & $(0.00756)$ & $(0.0206)$ & $(0.0322)$ & $(0.0316)$ \\
\hline \multirow[t]{2}{*}{ Board size (in logarithm) } & -0.00224 & -0.00194 & -0.00000609 & -0.00215 \\
\hline & $(0.00595)$ & $(0.0157)$ & $(0.0221)$ & $(0.0218)$ \\
\hline \multirow[t]{2}{*}{ Constant } & $0.317^{* * *}$ & $0.575^{\star \star *}$ & $1.017^{* * *}$ & $1.037^{* * *}$ \\
\hline & $(0.0455)$ & $(0.160)$ & $(0.171)$ & $(0.168)$ \\
\hline Number of observations & 17587 & 17587 & 17587 & 17587 \\
\hline $\mathrm{R} 2$ & 0.0267 & 0.0253 & 0.0386 & 0.0348 \\
\hline F test & 13.66 & 10.44 & 8.696 & 7.813 \\
\hline Number of firms & 2245 & 2245 & 2245 & 2245 \\
\hline
\end{tabular}

Note: OLS with fixed firm, year and industry effects. Standard errors in parentheses. * indicate p values, * significance at the $10 \%$, ${ }^{*}$ at the $5 \%$ and ${ }^{* * *}$ at the $1 \%$ level. Time-varying explanatory variables are lagged to reduce the simultaneity problem.

Source: Authors' estimation based on the CSMAR database.

\section{Addressing endogeneity - estimation by difference-in-differences and system GMM}

To address the endogeneity problem between board structure and firm performance, first the differencein-differences (DiD) estimation method is applied. The introduction of the regulation in 2002 to have at least a third of all directors independent by end-June 2003 provides an opportunity to check the different impacts of the regulation on firms affected by the regulation (i.e. the treatment group) and the ones not affected (i.e. the control group). This setting addresses the endogeneity problem as the change in board 
structure was triggered by a regulation and is not endogenously driven by firm characteristics. The DiD estimation equation is set up as follows:

$$
\text { Performance }_{i, t}=\alpha+\beta_{1} \text { treated }_{i} * \text { postregulation }_{t}+\beta_{2} \text { control }_{i, t}+d_{i}+d_{t}+\varepsilon_{i, t}
$$

The cross term of (i) firms affected by the regulation that at least a third of directors must be independent (i.e. a dummy variable equal to 1 if a firm had less than a third of directors independent in 2002, the year before the regulation became effective and equal to 0 otherwise) and (ii) a dummy for the regulated period ( 1 from 2003 onwards and 0 before) is the key variable of interest. The number of observations in the case of the DiD estimation is somewhat fewer than in case of OLS as by definition only those firm series could be taken into account where the number of independent directors for 2002 is known.

The treated*post-regulation variable is not significant in any of the four equations, indicating that if controlling for endogeneity, the earlier found positive association of a greater share of independent directors with better performance can no longer be confirmed (Table 5, columns 1-4). The control variables appear with the same, expected signs as in the previous set of regressions and with similar levels of significance. In a separate regression, not restricting the sample to observations where productivity could be estimated, the coefficient on the treated*post-regulation variable was significant when ROA was used as a performance variable. This indicates that at the time when the requirement that at least one third of directors must be independent was introduced in 2002, profitability improved. This finding is in line with Liu et al. (2015), which also uses accounting measures of firm performance.

System-GMM was also applied to estimate equation (1) to address the endogeneity problem. In the model setting, leverage, sales growth, investment share in total assets, the size of the board, the share of independent directors and firm size (measured by total assets, in logarithm) were assumed to be endogenously determined. Once controlling for endogeneity, the coefficients on the share of independent directors variable are no longer significant (Table 5, columns 5-8). Leverage again appears to be harmful for firm performance, in particular productivity, where the impact is nearly double than on ROA, though only slightly higher than on ROE. Once controlling for endogeneity, investment's impact on productivity is large and highly statistically significant and so it is on the accounting performance indicators. Younger and larger firms are more productive if endogenous determination of firm size is allowed for.

Another question is whether the director of the board and the CEO being the same person affects performance. As in the other model settings, four explanatory variables were checked in both OLS with fixed effects and system-GMM with the same set of control variables as in the previous regressions. The coefficient on the dummy variable ( 1 if the director of the board and the CEO are the same person, 0 otherwise) was not significant in any of the above eight equations, in line with earlier findings in the literature. 
Table 5. The share of independent directors and firm performance by DiD and GMM

\begin{tabular}{|c|c|c|c|c|c|c|c|c|}
\hline & ROA & ROE & $\begin{array}{l}\text { TFP (Olley- } \\
\text { Pakes) }\end{array}$ & $\begin{array}{l}\text { TFP (OLS with fixed } \\
\text { effects) }\end{array}$ & ROA & ROE & $\begin{array}{l}\text { TFP (Olley- } \\
\text { Pakes) }\end{array}$ & $\begin{array}{c}\text { TFP (OLS with fixed } \\
\text { effects) }\end{array}$ \\
\hline & & & DiD & & \multicolumn{4}{|c|}{ GMM } \\
\hline & (1) & (2) & (3) & (4) & (5) & (6) & (7) & (8) \\
\hline Treated ${ }^{*}$ post-regulation & $\begin{array}{l}-0.00303 \\
(0.00547)\end{array}$ & $\begin{array}{l}-0.0285 \\
(0.0204)\end{array}$ & $\begin{array}{l}-0.0207 \\
(0.0235)\end{array}$ & $\begin{array}{c}-0.0206 \\
(0.0233)\end{array}$ & & & & \\
\hline Leverage ratio & $\begin{array}{l}-0.0122^{*} \\
(0.00642)\end{array}$ & $\begin{array}{l}-0.00103 \\
(0.0270)\end{array}$ & $\begin{array}{l}-0.147^{\star \star \star} \\
(0.0274)\end{array}$ & $\begin{array}{l}-0.156^{\star \star \star} \\
(0.0272)\end{array}$ & $\begin{array}{l}-0.130^{\star \star \star} \\
(0.0125)\end{array}$ & $\begin{array}{c}-0.218^{\star \star \star} \\
(0.0350)\end{array}$ & $\begin{array}{c}-0.254^{\star \star \star} \\
(0.0502)\end{array}$ & $\begin{array}{l}-0.264^{\star \star \star} \\
(0.0496)\end{array}$ \\
\hline Investment ratio & $\begin{array}{c}0.0398^{\star \star *} \\
(0.0123)\end{array}$ & $\begin{array}{c}0.108^{\star *} \\
(0.0452)\end{array}$ & $\begin{array}{c}0.0586 \\
(0.0493)\end{array}$ & $\begin{array}{c}0.0948^{*} \\
(0.0490)\end{array}$ & $\begin{array}{l}0.230^{\star * \star} \\
(0.0298)\end{array}$ & $\begin{array}{l}0.644^{\star \star \star} \\
(0.0803)\end{array}$ & $\begin{array}{c}0.381^{\star \star *} \\
(0.112)\end{array}$ & $\begin{array}{c}0.390^{\star \star \star} \\
(0.110)\end{array}$ \\
\hline Sales growth & $\begin{array}{l}0.00328^{* *} \\
(0.00154)\end{array}$ & $\begin{array}{l}0.00967^{* *} \\
(0.00471)\end{array}$ & $\begin{array}{c}0.00412 \\
(0.00435)\end{array}$ & $\begin{array}{c}0.00346 \\
(0.00414)\end{array}$ & $\begin{array}{c}0.00218 \\
(0.00222)\end{array}$ & $\begin{array}{c}0.00369 \\
(0.00515)\end{array}$ & $\begin{array}{c}-0.000105 \\
(0.00960)\end{array}$ & $\begin{array}{l}0.000277 \\
(0.00954)\end{array}$ \\
\hline Age (in logarithm) & $\begin{array}{c}-0.0355^{\star * *} \\
(0.00776)\end{array}$ & $\begin{array}{c}-0.0840^{* * *} \\
(0.0212)\end{array}$ & $\begin{array}{c}-0.0892^{\star * *} \\
(0.0329)\end{array}$ & $\begin{array}{c}-0.0822^{* *} \\
(0.0322)\end{array}$ & $\begin{array}{l}-0.0228^{* * *} \\
(0.00752)\end{array}$ & $\begin{array}{l}-0.0404^{*} \\
(0.0230)\end{array}$ & $\begin{array}{c}-0.0707^{* *} \\
(0.0296)\end{array}$ & $\begin{array}{c}-0.0725^{\star *} \\
(0.0300)\end{array}$ \\
\hline Total assets (in logarithm) & $0.00832^{* * *}$ & $-0.0145^{\star *}$ & -0.00138 & -0.00109 & $0.0219^{* * *}$ & $0.0707^{\star * *}$ & $0.0550^{\star * *}$ & $0.0554^{* * *}$ \\
\hline & $(0.00207)$ & $(0.00691)$ & $(0.00728)$ & $(0.00712)$ & $(0.00206)$ & $(0.00727)$ & $(0.0104)$ & $(0.0102)$ \\
\hline Private ownership dummy & $\begin{array}{c}0.00500 \\
(0.00679)\end{array}$ & $\begin{array}{l}0.0311^{* *} \\
(0.0153)\end{array}$ & $\begin{array}{l}0.0393 \\
(0.0298)\end{array}$ & $\begin{array}{l}0.0385 \\
(0.0290)\end{array}$ & $\begin{array}{l}0.0243^{* *} \\
(0.0105)\end{array}$ & $\begin{array}{l}0.0637^{* * *} \\
(0.0243)\end{array}$ & $\begin{array}{l}0.0402 \\
(0.0281)\end{array}$ & $\begin{array}{l}0.0409 \\
(0.0277)\end{array}$ \\
\hline Central SOE dummy & $\begin{array}{l}-0.00835 \\
(0.00797)\end{array}$ & $\begin{array}{l}-0.0223 \\
(0.0229)\end{array}$ & $\begin{array}{c}-0.0229 \\
(0.0328)\end{array}$ & $\begin{array}{c}-0.0211 \\
(0.0320)\end{array}$ & $\begin{array}{c}0.0101 \\
(0.0119)\end{array}$ & $\begin{array}{c}0.0234 \\
(0.0330)\end{array}$ & $\begin{array}{c}0.0261 \\
(0.0381)\end{array}$ & $\begin{array}{c}0.0331 \\
(0.0377)\end{array}$ \\
\hline Agency-controlled SOE dummy & $\begin{array}{l}-0.0115 \\
(0.0104)\end{array}$ & $\begin{array}{l}0.00797 \\
(0.0575)\end{array}$ & $\begin{array}{l}0.00475 \\
(0.0462)\end{array}$ & $\begin{array}{l}0.00554 \\
(0.0447)\end{array}$ & $\begin{array}{l}0.00597 \\
(0.0172)\end{array}$ & $\begin{array}{c}-0.0530 \\
(0.0633)\end{array}$ & $\begin{array}{c}0.0127 \\
(0.0565)\end{array}$ & $\begin{array}{c}0.0146 \\
(0.0550)\end{array}$ \\
\hline Local SOE dummy & $\begin{array}{l}-0.00513 \\
(0.00757)\end{array}$ & $\begin{array}{l}0.00427 \\
(0.0200)\end{array}$ & $\begin{array}{c}-0.00316 \\
(0.0308)\end{array}$ & $\begin{array}{r}-0.00282 \\
(0.0301)\end{array}$ & $\begin{array}{l}0.00898 \\
(0.0119)\end{array}$ & $\begin{array}{c}-0.000955 \\
(0.0295)\end{array}$ & $\begin{array}{c}0.0278 \\
(0.0353)\end{array}$ & $\begin{array}{c}0.0325 \\
(0.0350)\end{array}$ \\
\hline Share of independent directors & & & & & $\begin{array}{c}-0.0142 \\
(0.0280)\end{array}$ & $\begin{array}{l}-0.0431 \\
(0.0965)\end{array}$ & $\begin{array}{c}0.101 \\
(0.116)\end{array}$ & $\begin{array}{c}-0.0178 \\
(0.0592)\end{array}$ \\
\hline Size of the board (in logarithm) & $\begin{array}{c}-0.00484 \\
(0.00590)\end{array}$ & $\begin{array}{c}-0.00863 \\
(0.0155)\end{array}$ & $\begin{array}{l}-0.0135 \\
(0.0211)\end{array}$ & $\begin{array}{l}-0.0154 \\
(0.0208)\end{array}$ & $\begin{array}{l}0.00171 \\
(0.0101)\end{array}$ & $\begin{array}{c}0.0187 \\
(0.0342)\end{array}$ & $\begin{array}{l}0.00862 \\
(0.0432)\end{array}$ & $\begin{array}{l}-0.0127 \\
(0.0444)\end{array}$ \\
\hline Constant & $0.330^{\star \star \star}$ & $0.628^{\star \star \star}$ & $1.106^{\star \star \star}$ & $1.123^{\star \star \star}$ & $-0.440^{\star \star \star}$ & $-1.348^{\star * *}$ & $-0.467^{\star}$ & -0.395 \\
\hline & $(0.0457)$ & $(0.163)$ & $(0.170)$ & $(0.167)$ & $(0.0583)$ & $(0.169)$ & $(0.250)$ & $(0.247)$ \\
\hline Number of observations & 17496 & 17496 & 17496 & 17496 & 18849 & 18849 & 18849 & 18849 \\
\hline $\mathrm{R} 2$ & 0.0262 & 0.0250 & 0.0386 & 0.0347 & & & & \\
\hline F-test & 13.29 & 10.20 & 9.202 & 8.224 & & & & \\
\hline Number of firms & 2245 & 2245 & 2245 & 2245 & 2383 & 2383 & 2383 & 2383 \\
\hline
\end{tabular}

Note: Standard errors in parentheses. ${ }^{*}$ indicate $p$ values, ${ }^{*}$ significance at the $10 \%,{ }^{* *}$ at the $5 \%$ and ${ }^{* * *}$ at the $1 \%$ level. The cross term treated ${ }^{*}$ post-regulation is the interaction term of (i) firms affected by the regulation that at least a third of directors must be independent (i.e. a dummy variable equal to 1 if a firm had less than a third of directors independent in 2002 , the year before the regulation became eflective and equal to 0 otherwise) and (ii) a dummy for the regulated period (equals 1 from 2003 onwards and 0 before). In equations $1-4$ the time-varying explanatory variables are lagged to reduce the simultaneity problem. Firm, year and industry fixed effects are included in all equations.

Source: Authors' estimation based on the CSMAR database. 


\section{Incentive mechanisms}

In China the major incentive mechanism is salary, though offering shares to executives is becoming more common than before. Shares, however, are rarely offered to workers. As China is a transition economy, where the salary gap between workers and management has widened over the past decades from very small levels, it may be of greater interest to look at whether an increasing gap is tolerated instead of simply looking at the absolute levels of executive salaries. A priori, a greater salary gap is expected to be negatively associated with workers' efforts and hence firm performance as it may strengthen the perception of unfairness and inequity. Here the ratio of the average salary of executives to the average wage of workers is used to capture the salary gap. Firm-level fixed effects control for heterogeneity in firm and managerial quality. For instance, if managerial quality is correlated with firm performance and executives' salaries, then its omission may result in biased estimates of the relationship between the latter two. To examine how the salary gap affects firm performance, the following equation was estimated, where the salary gap is the key variable of interest:

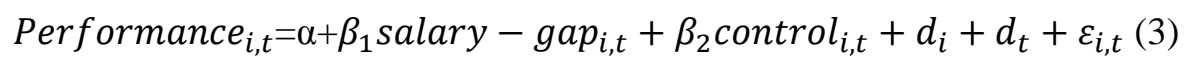

As in the above sets of regressions, OLS with fixed effects and system-GMM were applied. In the OLS regressions all time-varying explanatory variables are lagged to reduce the simultaneity problem. The salary gap appears to negatively affect productivity, though only in the system-GMM equations, where endogeneity is addressed (Table 6, columns 5-8). In contrast, the salary gap positively affects returns on assets or equity in all equations (columns 1-4). Beyond the efficiency wage theory, the Chinese incentivebased salary system provides an explanation. ROA and ROE are often among the objectives of executives and thus the criteria by which their performance is assessed. This creates a mechanism where managers seek higher profits, which are reflected in their higher pay. Insofar as executives' salaries are not explicitly linked to productivity measures, they may seek to boost returns at the expense of productivity, for instance through mere volume expansion or through cutting corners in the pursuit of short-term profits.

Next it is checked whether shareholding by executives enhances firm performance. The ratio of shares that executives hold to total outstanding shares captures this variable, and is used as the explanatory variable in equation (3) in place of the salary gap. In the OLS regressions with fixed firm and time effects, the greater amount of shares executives hold the higher the performance of the firm is, but in the system-GMM regressions the coefficient on the executive shareholding variable is not significant in any of the four equations (Table 7). As the system-GMM addresses endogeneity, the estimates are more reliable. Hence, executive shareholding may not affect firm performance, probably because of the still low use of this incentive tool. 
Table 6. Relative salaries and firm performance

\begin{tabular}{|c|c|c|c|c|c|c|c|c|}
\hline & \multicolumn{2}{|c|}{$\mathrm{ROA}$} & \multicolumn{2}{|c|}{ ROE } & \multicolumn{2}{|c|}{ TFP (Olley-Pakes) } & \multicolumn{2}{|c|}{ TFP (OLS with fixed effects) } \\
\hline & $\begin{array}{l}\text { OLS with } \\
\text { fixed } \\
\text { effects }\end{array}$ & GMM & $\begin{array}{l}\text { OLS with fixed } \\
\text { effects }\end{array}$ & GMM & $\begin{array}{l}\text { OLS with fixed } \\
\text { effects }\end{array}$ & GMM & $\begin{array}{l}\text { OLS with fixed } \\
\text { effects }\end{array}$ & GMM \\
\hline & (1) & (2) & (3) & (4) & (5) & (6) & (7) & (8) \\
\hline Salary gap & $\begin{array}{l}0.00106^{\star \star *} \\
(0.000203)\end{array}$ & $\begin{array}{c}0.000804^{* * *} \\
(0.000296)\end{array}$ & $\begin{array}{l}0.00251^{* * *} \\
(0.000520)\end{array}$ & $\begin{array}{c}0.00160^{\star *} \\
(0.000745)\end{array}$ & $\begin{array}{c}0.000845 \\
(0.000644)\end{array}$ & $\begin{array}{l}-0.00169^{* *} \\
(0.000798)\end{array}$ & $\begin{array}{c}0.000269 \\
(0.000635)\end{array}$ & $\begin{array}{c}-0.00212^{\star * *} \\
(0.000790)\end{array}$ \\
\hline Leverage ratio & $\begin{array}{l}-0.00885 \\
(0.00670)\end{array}$ & $\begin{array}{l}-0.126^{\star \star \star} \\
(0.0120)\end{array}$ & $\begin{array}{l}0.00218 \\
(0.0282)\end{array}$ & $\begin{array}{l}-0.206^{* \star *} \\
(0.0359)\end{array}$ & $\begin{array}{l}-0.145^{\star \star \star} \\
(0.0279)\end{array}$ & $\begin{array}{l}-0.247^{* * *} \\
(0.0511)\end{array}$ & $\begin{array}{l}-0.154^{* \star *} \\
(0.0278)\end{array}$ & $\begin{array}{l}-0.258^{* \star *} \\
(0.0503)\end{array}$ \\
\hline Investment ratio & $\begin{array}{l}0.0358^{* * *} \\
(0.0122)\end{array}$ & $\begin{array}{l}0.218^{* \star \star} \\
(0.0290)\end{array}$ & $\begin{array}{l}0.0978^{\star *} \\
(0.0451)\end{array}$ & $\begin{array}{l}0.615^{\star * \star} \\
(0.0827)\end{array}$ & $\begin{array}{c}0.0465 \\
(0.0503)\end{array}$ & $\begin{array}{l}0.428^{* * *} \\
(0.118)\end{array}$ & $\begin{array}{l}0.0841^{*} \\
(0.0500)\end{array}$ & $\begin{array}{c}0.432^{* * *} \\
(0.115)\end{array}$ \\
\hline Sales growth & $\begin{array}{l}0.00308^{\star *} \\
(0.00150)\end{array}$ & $\begin{array}{c}0.00375 \\
(0.00284)\end{array}$ & $\begin{array}{l}0.00920^{* *} \\
(0.00463)\end{array}$ & $\begin{array}{c}0.00840 \\
(0.00674)\end{array}$ & $\begin{array}{c}0.00258 \\
(0.00418)\end{array}$ & $\begin{array}{l}-0.00152 \\
(0.0104)\end{array}$ & $\begin{array}{c}0.00198 \\
(0.00402)\end{array}$ & $\begin{array}{l}-0.00119 \\
(0.0104)\end{array}$ \\
\hline Age (in logarithm) & $\begin{array}{c}-0.0459^{\star * *} \\
(0.00963)\end{array}$ & $\begin{array}{l}-0.0226^{\star \star *} \\
(0.00823)\end{array}$ & $\begin{array}{l}-0.112^{* * *} \\
(0.0264)\end{array}$ & $\begin{array}{l}-0.0441^{*} \\
(0.0243)\end{array}$ & $\begin{array}{l}-0.105^{\star * \star} \\
(0.0408)\end{array}$ & $\begin{array}{l}-0.0595^{*} \\
(0.0318)\end{array}$ & $\begin{array}{c}-0.0969^{* *} \\
(0.0400)\end{array}$ & $\begin{array}{l}-0.0582^{*} \\
(0.0315)\end{array}$ \\
\hline Total assets (in logarithm) & $\begin{array}{c}0.00986^{* * *} \\
(0.00212)\end{array}$ & $\begin{array}{l}0.0207^{\star * *} \\
(0.00200)\end{array}$ & $\begin{array}{l}-0.0175^{\star *} \\
(0.00720)\end{array}$ & $\begin{array}{l}0.0674^{* * *} \\
(0.00750)\end{array}$ & $\begin{array}{l}0.000134 \\
(0.00718)\end{array}$ & $\begin{array}{l}0.0561^{* * *} \\
(0.0108)\end{array}$ & $\begin{array}{l}0.000872 \\
(0.00707)\end{array}$ & $\begin{array}{c}0.0569^{* * *} \\
(0.0106)\end{array}$ \\
\hline Private ownership dummy & $\begin{array}{c}0.00635 \\
(0.00692)\end{array}$ & $\begin{array}{l}0.0245^{* *} \\
(0.0106)\end{array}$ & $\begin{array}{l}0.0369^{* *} \\
(0.0161)\end{array}$ & $\begin{array}{l}0.0577^{\star *} \\
(0.0246)\end{array}$ & $\begin{array}{c}0.0327 \\
(0.0317)\end{array}$ & $\begin{array}{c}0.0353 \\
(0.0285)\end{array}$ & $\begin{array}{c}0.0318 \\
(0.0310)\end{array}$ & $\begin{array}{c}0.0371 \\
(0.0281)\end{array}$ \\
\hline Central SOE dummy & $\begin{array}{l}-0.00783 \\
(0.00800)\end{array}$ & $\begin{array}{c}0.0131 \\
(0.0120)\end{array}$ & $\begin{array}{l}-0.0194 \\
(0.0235)\end{array}$ & $\begin{array}{c}0.0220 \\
(0.0340)\end{array}$ & $\begin{array}{l}-0.0326 \\
(0.0341)\end{array}$ & $\begin{array}{c}0.0159 \\
(0.0389)\end{array}$ & $\begin{array}{l}-0.0311 \\
(0.0334)\end{array}$ & $\begin{array}{c}0.0219 \\
(0.0385)\end{array}$ \\
\hline Local SOE dummy & $\begin{array}{l}-0.00332 \\
(0.00781)\end{array}$ & $\begin{array}{c}0.0106 \\
(0.0121)\end{array}$ & $\begin{array}{c}0.0123 \\
(0.0216)\end{array}$ & $\begin{array}{l}0.00116 \\
(0.0300)\end{array}$ & $\begin{array}{l}-0.00875 \\
(0.0324)\end{array}$ & $\begin{array}{c}0.0262 \\
(0.0356)\end{array}$ & $\begin{array}{l}-0.00914 \\
(0.0318)\end{array}$ & $\begin{array}{c}0.0302 \\
(0.0352)\end{array}$ \\
\hline Size of board (in logarithm) & $\begin{array}{l}-0.00480 \\
(0.00603)\end{array}$ & $\begin{array}{c}0.0170 \\
(0.0109)\end{array}$ & $\begin{array}{l}-0.0103 \\
(0.0162)\end{array}$ & $\begin{array}{c}0.0367 \\
(0.0350)\end{array}$ & $\begin{array}{l}-0.0110 \\
(0.0215)\end{array}$ & $\begin{array}{c}0.0221 \\
(0.0442)\end{array}$ & $\begin{array}{l}-0.0127 \\
(0.0212)\end{array}$ & $\begin{array}{c}0.0153 \\
(0.0444)\end{array}$ \\
\hline Constant & $\begin{array}{l}0.384^{* \star *} \\
(0.0492)\end{array}$ & $\begin{array}{l}-0.464^{\star \star \star} \\
(0.0664)\end{array}$ & $\begin{array}{c}0.743^{\star \star \star} \\
(0.177)\end{array}$ & $\begin{array}{c}-1.320^{\star \star *} \\
(0.170)\end{array}$ & $\begin{array}{l}1.105^{\star \star \star} \\
(0.177)\end{array}$ & $\begin{array}{l}-0.558^{\star *} \\
(0.262)\end{array}$ & $\begin{array}{c}1.112^{* \star *} \\
(0.174)\end{array}$ & $\begin{array}{c}-0.547^{\star \star} \\
(0.258)\end{array}$ \\
\hline Number of observations & 17214 & 18714 & 17214 & 18714 & 17214 & 18714 & 17214 & 18714 \\
\hline $\mathrm{R} 2$ & 0.0302 & & 0.0287 & & 0.0380 & & 0.0339 & \\
\hline F-test & 14.87 & & 12.30 & & 9.332 & & 8.135 & \\
\hline Number of firms & 2243 & 2383 & 2243 & 2383 & 2243 & 2383 & 2243 & 2383 \\
\hline
\end{tabular}

Note: Standard errors in parentheses. * indicate $p$ values, ${ }^{*}$ significance at the $10 \%$, ${ }^{* *}$ at the $5 \%$ and ${ }^{* * *}$ at the $1 \%$ level. The salary gap is the ratio of average executive salary to

average workers' wages. Time-varying explanatory variables in the OLS equations are lagged to reduce the simultaneity problem. Firm, year and industry fixed effects are included in all equations.

Source: Authors' estimation based on the CSMAR database. 
Table 7. Executive shareholding and firm performance

\begin{tabular}{|c|c|c|c|c|c|c|c|c|}
\hline & \multicolumn{2}{|c|}{$\mathrm{ROA}$} & \multicolumn{2}{|c|}{$\mathrm{ROE}$} & \multicolumn{2}{|c|}{ TFP (Olley-Pakes) } & \multicolumn{2}{|c|}{ TFP (OLS with fixed effects) } \\
\hline & $\begin{array}{l}\text { OLS with fixed } \\
\text { effects }\end{array}$ & GMM & $\begin{array}{l}\text { OLS with fixed } \\
\text { effects }\end{array}$ & GMM & $\begin{array}{l}\text { OLS with fixed } \\
\text { effects }\end{array}$ & GMM & $\begin{array}{l}\text { OLS with fixed } \\
\text { effects }\end{array}$ & GMM \\
\hline & (1) & (2) & (3) & (4) & (5) & (6) & (7) & (8) \\
\hline Executive shareholding & $\begin{array}{l}0.0814^{* * *} \\
(0.0249)\end{array}$ & $\begin{array}{c}0.0155 \\
(0.0347)\end{array}$ & $\begin{array}{l}0.153^{* * *} \\
(0.0501)\end{array}$ & $\begin{array}{l}0.00737 \\
(0.0589)\end{array}$ & $\begin{array}{l}0.224^{* * *} \\
(0.0711)\end{array}$ & $\begin{array}{c}0.103 \\
(0.0880)\end{array}$ & $\begin{array}{l}0.224^{* * *} \\
(0.0703)\end{array}$ & $\begin{array}{c}0.103 \\
(0.0868)\end{array}$ \\
\hline Leverage ratio & $\begin{array}{l}-0.00994 \\
(0.00670)\end{array}$ & $\begin{array}{l}-0.128^{* * *} \\
(0.0142)\end{array}$ & $\begin{array}{l}0.00129 \\
(0.0286)\end{array}$ & $\begin{array}{l}-0.191^{\star * *} \\
(0.0364)\end{array}$ & $\begin{array}{l}-0.143^{* * *} \\
(0.0278)\end{array}$ & $\begin{array}{c}-0.232^{* * *} \\
(0.0542)\end{array}$ & $\begin{array}{l}-0.152^{* * *} \\
(0.0277)\end{array}$ & $\begin{array}{c}-0.246^{\star * *} \\
(0.0534)\end{array}$ \\
\hline Investment ratio & $\begin{array}{c}0.0394^{\star \star *} \\
(0.0125)\end{array}$ & $\begin{array}{l}0.214^{\star \star \star} \\
(0.0287)\end{array}$ & $\begin{array}{l}0.101^{* \star} \\
(0.0471)\end{array}$ & $\begin{array}{l}0.573^{\star \star \star} \\
(0.0837)\end{array}$ & $\begin{array}{c}0.0502 \\
(0.0512)\end{array}$ & $\begin{array}{l}0.281^{* *} \\
(0.113)\end{array}$ & $\begin{array}{l}0.0872^{*} \\
(0.0508)\end{array}$ & $\begin{array}{c}0.289^{* * *} \\
(0.111)\end{array}$ \\
\hline Sales growth & $\begin{array}{l}0.00305^{\star *} \\
(0.00145)\end{array}$ & $\begin{array}{c}0.00227 \\
(0.00233)\end{array}$ & $\begin{array}{l}0.00946^{\star *} \\
(0.00464)\end{array}$ & $\begin{array}{c}0.00300 \\
(0.00475)\end{array}$ & $\begin{array}{c}0.00390 \\
(0.00438)\end{array}$ & $\begin{array}{l}-0.00111 \\
(0.00989)\end{array}$ & $\begin{array}{c}0.00323 \\
(0.00417)\end{array}$ & $\begin{array}{r}-0.000709 \\
(0.00981)\end{array}$ \\
\hline Age (in logarithm) & $\begin{array}{c}-0.0419^{* * *} \\
(0.00960)\end{array}$ & $\begin{array}{c}-0.0314^{* * *} \\
(0.00729)\end{array}$ & $\begin{array}{c}-0.0909^{* * *} \\
(0.0260)\end{array}$ & $\begin{array}{l}-0.0295 \\
(0.0241)\end{array}$ & $\begin{array}{l}-0.114^{\star * *} \\
(0.0401)\end{array}$ & $\begin{array}{c}-0.0560^{* \star} \\
(0.0277)\end{array}$ & $\begin{array}{l}-0.106^{* * \star} \\
(0.0393)\end{array}$ & $\begin{array}{c}-0.0546^{\star \star} \\
(0.0273)\end{array}$ \\
\hline Total assets (in logarithm) & $\begin{array}{c}-0.00838^{* * *} \\
(0.00218)\end{array}$ & $\begin{array}{l}0.0229^{* * *} \\
(0.00229)\end{array}$ & $\begin{array}{l}-0.0145^{\star *} \\
(0.00719)\end{array}$ & $\begin{array}{l}0.0698^{\star \star *} \\
(0.00792)\end{array}$ & $\begin{array}{c}-0.000226 \\
(0.00766)\end{array}$ & $\begin{array}{c}0.0571^{* * *} \\
(0.0115)\end{array}$ & $\begin{array}{c}0.0000555 \\
(0.00750)\end{array}$ & $\begin{array}{c}0.0574^{* * *} \\
(0.0112)\end{array}$ \\
\hline \multirow[t]{2}{*}{ Private ownership dummy } & 0.00488 & $0.0209^{*}$ & $0.0298^{*}$ & $0.0654^{\star *}$ & 0.0292 & 0.0311 & 0.0282 & 0.0333 \\
\hline & $(0.00702)$ & $(0.0114)$ & $(0.0156)$ & $(0.0266)$ & $(0.0316)$ & $(0.0288)$ & $(0.0309)$ & $(0.0286)$ \\
\hline \multirow[t]{2}{*}{ Central SOE dummy } & -0.00941 & 0.0164 & -0.0240 & 0.0228 & -0.0348 & 0.0180 & -0.0330 & 0.0257 \\
\hline & $(0.00824)$ & $(0.0131)$ & $(0.0234)$ & $(0.0353)$ & $(0.0349)$ & $(0.0410)$ & $(0.0341)$ & $(0.0404)$ \\
\hline \multirow[t]{2}{*}{ Agency-controlled SOE dummy } & -0.0108 & 0.0108 & 0.0142 & -0.0520 & -0.00483 & 0.0173 & -0.00455 & 0.0187 \\
\hline & $(0.0108)$ & $(0.0173)$ & $(0.0607)$ & $(0.0703)$ & $(0.0481)$ & $(0.0611)$ & $(0.0467)$ & $(0.0592)$ \\
\hline \multirow[t]{2}{*}{ Local SOE dummy } & -0.00561 & 0.00760 & 0.00432 & -0.000335 & -0.0134 & 0.0228 & -0.0134 & 0.0272 \\
\hline & $(0.00789)$ & $(0.0131)$ & $(0.0207)$ & $(0.0314)$ & $(0.0336)$ & $(0.0377)$ & $(0.0329)$ & $(0.0371)$ \\
\hline \multirow[t]{2}{*}{ Size of board (in logarithm) } & -0.00488 & 0.00277 & -0.00992 & 0.0201 & -0.0132 & -0.0178 & -0.0148 & -0.0258 \\
\hline & $(0.00595)$ & $(0.0101)$ & $(0.0156)$ & $(0.0330)$ & $(0.0214)$ & $(0.0450)$ & $(0.0211)$ & $(0.0451)$ \\
\hline \multirow[t]{2}{*}{ Constant } & $0.348^{\star \star \star}$ & $-0.385^{\star \star \star}$ & $0.637^{\star \star *}$ & $-1.212^{\star \star \star}$ & $1.153^{\star \star *}$ & $-0.723^{\star \star}$ & $1.166^{\star \star \star}$ & $-0.681^{\star *}$ \\
\hline & $(0.0496)$ & $(0.0589)$ & $(0.177)$ & $(0.208)$ & $(0.184)$ & $(0.284)$ & $(0.180)$ & $(0.279)$ \\
\hline Number of observations & 16697 & 17900 & 16697 & 17900 & 16697 & 17900 & 16697 & 17900 \\
\hline $\mathrm{R} 2$ & 0.0264 & & 0.0242 & & 0.0395 & & 0.0355 & \\
\hline F-test & 13.21 & & 9.515 & & 8.705 & & 7.890 & \\
\hline Number of firms & 2240 & 2380 & 2240 & 2380 & 2240 & 2380 & 2240 & 2380 \\
\hline
\end{tabular}

Note: Standard errors in parentheses. * indicate p values, ${ }^{*}$ significance at the $10 \%$, ${ }^{*}$ at the $5 \%$ and ${ }^{* * *}$ at the $1 \%$ level. Executive shareholding is the ratio of shares that executives hold to total outstanding shares. Time-varying explanatory variables in the OLS equations are lagged to reduce the simultaneity problem. Firm, year and industry fixed effects are included in all equations.

Source: Authors' estimation based on the CSMAR database. 


\section{Ownership structures}

Another important question is how ownership structure affects firm performance. First, ownership concentration is examined. Although ownership concentration has decreased in the past decade, it is still high. Two measures are used to capture this variable, the share of the largest shareholder and that of the ten largest shareholders. Next, the impact on firm performance of institutional investors is examined.

\section{Ownership concentration}

Very high ownership concentration of Chinese listed firms is a long-standing problem. The biggest shareholder owns at least a third of the shares in half of the listed firms and more than half in nearly a fifth. High ownership concentration makes protecting minority shareholders from expropriation difficult. As the 2017 OECD Economic Survey of China (OECD, 2017) points out, shareholders have used myriads of ways to siphon large amounts of funds from their firms. To examine how ownership concentration affects firm performance, the following equation is estimated, where the share of the largest shareholder is the key variable of interest:

$$
\text { Performance }_{i, t}=\alpha+\beta_{1} \text { ownership }_{i, t}+\beta_{2} \text { control }_{i, t}+d_{i}+d_{t}+\varepsilon_{i, t}(4)
$$

The larger the share held by the biggest shareholder, the worse the firm's performance, judging from the GMM results, where the coefficient on this variable is negative and significant, though in the case of TFP measures, only significant at the $10 \%$ level (Table 8). Although the size of the coefficient is very small (a $1 \%$ increase in the shareholding of the biggest shareholder would lead to a $0.06 \%$ decrease in TFP), the negative effect is consistent across various model settings.

Using an alternative ownership variable, the impact of the share of the ten largest shareholders on firm performance is also estimated. In contrast with the previous set of regressions, it turns out that the greater the share held by the ten biggest shareholders, the better firm performance (Table 9). Moreover, the coefficients are highly significant (at the $1 \%$ level) in all eight equations, even though they are again very small. A $1 \%$ increase in the shareholding of the ten biggest shareholders would boost productivity by $0.2 \%$ and ROA and ROE to an even lesser extent. These results may indicate that excessive concentration (i.e. an overly high share held by a single shareholder) is harmful, but that a certain degree of concentration (here proxied as holdings by the ten biggest shareholders) may improve performance.

Indeed, there are trade-offs and there may be thresholds in ownership concentration. While large shareholders tend to monitor better and ownership concentration reduces the free-rider problem of having many dispersed shareholders, control rights are more readily abused when there are too few shareholders. Moreover, coordination and consensus building among several large shareholders may be costly. The Chinese Code of Corporate Governance advocates a "reasonably balanced shareholding" structure (Article 1, Chapter 2), which can be interpreted as several large shareholders, mid-way between overly dispersed and overly concentrated ownership. 
Table 8. Shareholding by the largest shareholder and firm performance

ECO/WKP(2017)53

\begin{tabular}{|c|c|c|c|c|c|c|c|c|}
\hline & \multicolumn{2}{|c|}{$\mathrm{ROA}$} & \multicolumn{2}{|c|}{ ROE } & \multicolumn{2}{|c|}{ TFP (Olley-Pakes) } & \multicolumn{2}{|c|}{ TFP (OLS with fixed effects) } \\
\hline & $\begin{array}{l}\text { OLS with } \\
\text { fixed effects }\end{array}$ & GMM & $\begin{array}{l}\text { OLS with fixed } \\
\text { effects }\end{array}$ & GMM & $\begin{array}{l}\text { OLS with fixed } \\
\text { effects }\end{array}$ & GMM & $\begin{array}{l}\text { OLS with fixed } \\
\text { effects }\end{array}$ & GMM \\
\hline & (1) & (2) & (3) & (4) & (5) & (6) & (7) & (8) \\
\hline $\begin{array}{l}\text { Shares held by the largest } \\
\text { shareholder }\end{array}$ & $\begin{array}{c}-0.000102 \\
(0.0000767)\end{array}$ & $\begin{array}{c}-0.000351^{* * *} \\
(0.000106)\end{array}$ & $\begin{array}{l}-0.000245 \\
(0.000203)\end{array}$ & $\begin{array}{c}-0.000737^{* *} \\
(0.000308)\end{array}$ & $\begin{array}{l}-0.000268 \\
(0.000238)\end{array}$ & $\begin{array}{l}-0.000590^{*} \\
(0.000314)\end{array}$ & $\begin{array}{l}-0.000216 \\
(0.000235)\end{array}$ & $\begin{array}{l}-0.000573 \\
(0.000312)\end{array}$ \\
\hline Leverage ratio & $\begin{array}{l}-0.00291 \\
(0.00754)\end{array}$ & $\begin{array}{l}-0.138^{\star * \star} \\
(0.0122)\end{array}$ & $\begin{array}{l}0.0144 \\
(0.0321)\end{array}$ & $\begin{array}{l}-0.234^{\star \star *} \\
(0.0349)\end{array}$ & $\begin{array}{l}-0.135^{\star \star \star} \\
(0.0302)\end{array}$ & $\begin{array}{l}-0.272^{\star * *} \\
(0.0557)\end{array}$ & $\begin{array}{l}-0.142^{\star * \star} \\
(0.0300)\end{array}$ & $\begin{array}{l}-0.280^{\star \star \star} \\
(0.0547)\end{array}$ \\
\hline Investment ratio & $\begin{array}{l}0.0245^{\star} \\
(0.0135)\end{array}$ & $\begin{array}{l}0.207^{\star * *} \\
(0.0283)\end{array}$ & $\begin{array}{c}0.0714 \\
(0.0507)\end{array}$ & $\begin{array}{l}0.570^{* \star *} \\
(0.0814)\end{array}$ & $\begin{array}{l}0.00678 \\
(0.0489)\end{array}$ & $\begin{array}{c}0.405^{* * *} \\
(0.121)\end{array}$ & $\begin{array}{c}0.0409 \\
(0.0485)\end{array}$ & $\begin{array}{c}0.403^{\star * *} \\
(0.118)\end{array}$ \\
\hline Sales growth & $\begin{array}{l}0.00276^{\star *} \\
(0.00137)\end{array}$ & $\begin{array}{c}0.00257 \\
(0.00261)\end{array}$ & $\begin{array}{l}0.00858^{*} \\
(0.00442)\end{array}$ & $\begin{array}{c}0.00571 \\
(0.00593)\end{array}$ & $\begin{array}{c}0.00234 \\
(0.00389)\end{array}$ & $\begin{array}{l}-0.00195 \\
(0.00993)\end{array}$ & $\begin{array}{c}0.00186 \\
(0.00374)\end{array}$ & $\begin{array}{l}-0.00128 \\
(0.00984)\end{array}$ \\
\hline Age (in logarithm) & $\begin{array}{c}-0.0622^{* * *} \\
(0.0126)\end{array}$ & $\begin{array}{l}-0.0181 \\
(0.0111)\end{array}$ & $\begin{array}{l}-0.168^{* * *} \\
(0.0364)\end{array}$ & $\begin{array}{l}-0.00976 \\
(0.0279)\end{array}$ & $\begin{array}{l}-0.161^{* * *} \\
(0.0470)\end{array}$ & $\begin{array}{l}-0.0707^{\star} \\
(0.0405)\end{array}$ & $\begin{array}{l}-0.150^{* \star \star} \\
(0.0460)\end{array}$ & $\begin{array}{l}-0.0687^{*} \\
(0.0399)\end{array}$ \\
\hline Total assets (in logarithm) & $-0.0104^{* * *}$ & $0.0228^{* * *}$ & $-0.0174^{* *}$ & $0.0720^{* * *}$ & 0.00174 & $0.0527^{* * *}$ & 0.00238 & $0.0526^{* * *}$ \\
\hline Private ownership dummy & $\begin{array}{c}(0.00212) \\
0.0111 \\
(0.00935)\end{array}$ & $\begin{array}{c}(0.00211) \\
0.0253^{\star \star} \\
(0.0105)\end{array}$ & $\begin{array}{c}(0.00817) \\
0.0613^{\star * \star} \\
(0.0195)\end{array}$ & $\begin{array}{c}(0.00726) \\
0.0659^{\star * *} \\
(0.0245)\end{array}$ & $\begin{array}{c}(0.00822) \\
0.0527 \\
(0.0351)\end{array}$ & $\begin{array}{c}(0.0115) \\
0.0349 \\
(0.0276)\end{array}$ & $\begin{array}{c}(0.00809) \\
0.0505 \\
(0.0341)\end{array}$ & $\begin{array}{c}(0.0112) \\
0.0368 \\
(0.0272)\end{array}$ \\
\hline Central SOE dummy & $\begin{array}{l}-0.00408 \\
(0.00954)\end{array}$ & $\begin{array}{c}0.0139 \\
(0.0119)\end{array}$ & $\begin{array}{c}-0.000230 \\
(0.0286)\end{array}$ & $\begin{array}{c}0.0172 \\
(0.0332)\end{array}$ & $\begin{array}{l}-0.0203 \\
(0.0380)\end{array}$ & $\begin{array}{c}0.0354 \\
(0.0379)\end{array}$ & $\begin{array}{l}-0.0189 \\
(0.0370)\end{array}$ & $\begin{array}{c}0.0406 \\
(0.0374)\end{array}$ \\
\hline Local SOE dummy & $\begin{array}{c}0.00440 \\
(0.00875)\end{array}$ & $\begin{array}{c}0.0132 \\
(0.0117)\end{array}$ & $\begin{array}{l}0.0429^{*} \\
(0.0252)\end{array}$ & $\begin{array}{l}0.00859 \\
(0.0283)\end{array}$ & $\begin{array}{l}0.0135 \\
(0.0348)\end{array}$ & $\begin{array}{c}0.0383 \\
(0.0339)\end{array}$ & $\begin{array}{c}0.0117 \\
(0.0338)\end{array}$ & $\begin{array}{l}0.0415 \\
(0.0336)\end{array}$ \\
\hline Size of board (in logarithm) & $\begin{array}{l}-0.00990 \\
(0.00692)\end{array}$ & $\begin{array}{c}0.0172 \\
(0.0124)\end{array}$ & $\begin{array}{l}-0.0235 \\
(0.0181)\end{array}$ & $\begin{array}{c}0.0392 \\
(0.0394)\end{array}$ & $\begin{array}{l}-0.0188 \\
(0.0218)\end{array}$ & $\begin{array}{l}-0.0106 \\
(0.0454)\end{array}$ & $\begin{array}{l}-0.0202 \\
(0.0217)\end{array}$ & $\begin{array}{l}-0.0177 \\
(0.0455)\end{array}$ \\
\hline Constant & $\begin{array}{l}0.455^{\star \star \star} \\
(0.0590)\end{array}$ & $\begin{array}{c}-0.466^{* * *} \\
(0.0682)\end{array}$ & $\begin{array}{c}0.923^{\star \star \star} \\
(0.216)\end{array}$ & $\begin{array}{c}-1.482^{\star * *} \\
(0.164)\end{array}$ & $\begin{array}{c}1.237^{\star \star \star} \\
(0.210)\end{array}$ & $\begin{array}{c}-0.697^{\star *} \\
(0.311)\end{array}$ & $\begin{array}{c}1.231^{* \star \star} \\
(0.206)\end{array}$ & $\begin{array}{l}-0.422^{*} \\
(0.247)\end{array}$ \\
\hline Number of observations & 15255 & 17474 & 15255 & 17474 & 15255 & 17474 & 15255 & 17474 \\
\hline R2 & 0.0268 & & 0.0281 & & 0.0304 & & 0.0271 & \\
\hline F-test & 14.29 & & 11.97 & & 8.099 & & 7.172 & \\
\hline Number of firms & 2239 & 2382 & 2239 & 2382 & 2239 & 2382 & 2239 & 2382 \\
\hline
\end{tabular}

Note: Standard errors in parentheses. * indicate p values, ${ }^{*}$ significance at the $10 \%,{ }^{* *}$ at the $5 \%$ and ${ }^{* * *}$ at the $1 \%$ level. Shares held by the largest shareholder is the share of stocks in total outstanding held by the largest shareholder. Time-varying explanatory variables in the OLS equations are lagged to reduce the simultaneity problem. Firm, year and industry fixed effects are included in all equations.

Source: Authors' estimation based on the CSMAR database. 
Table 9. Shareholding by the ten largest shareholders and firm performance

\begin{tabular}{|c|c|c|c|c|c|c|c|c|}
\hline & \multicolumn{2}{|c|}{$\mathrm{ROA}$} & \multicolumn{2}{|c|}{ ROE } & \multicolumn{2}{|c|}{ TFP (Olley-Pakes) } & \multicolumn{2}{|c|}{ TFP (OLS with fixed effects) } \\
\hline & $\begin{array}{l}\text { OLS with } \\
\text { fixed } \\
\text { effects }\end{array}$ & GMM & $\begin{array}{l}\text { OLS with fixed } \\
\text { effects }\end{array}$ & GMM & $\begin{array}{l}\text { OLS with fixed } \\
\text { effects }\end{array}$ & GMM & $\begin{array}{l}\text { OLS with fixed } \\
\text { effects }\end{array}$ & GMM \\
\hline & $(1)$ & $(2)$ & (3) & (4) & $(5)$ & (6) & (7) & (8) \\
\hline $\begin{array}{l}\text { Shares held by the ten largest } \\
\text { shareholders }\end{array}$ & $\begin{array}{l}0.00124^{* * *} \\
(0.000104)\end{array}$ & $\begin{array}{c}0.000906^{* * *} \\
(0.000138)\end{array}$ & $\begin{array}{l}0.00353^{* * *} \\
(0.000277)\end{array}$ & $\begin{array}{l}0.00192^{* * *} \\
(0.000409)\end{array}$ & $\begin{array}{l}0.00387^{* * *} \\
(0.000366)\end{array}$ & $\begin{array}{l}0.00219^{* * *} \\
(0.000508)\end{array}$ & $\begin{array}{l}0.00373^{* * *} \\
(0.000361)\end{array}$ & $\begin{array}{l}0.00219^{* * *} \\
(0.000506)\end{array}$ \\
\hline Leverage ratio & $\begin{array}{c}0.00672 \\
(0.00749)\end{array}$ & $\begin{array}{l}-0.129^{* * \star} \\
(0.0117)\end{array}$ & $\begin{array}{l}0.0417 \\
(0.0322)\end{array}$ & $\begin{array}{l}-0.227^{* \star *} \\
(0.0346)\end{array}$ & $\begin{array}{l}-0.105^{* * *} \\
(0.0301)\end{array}$ & $\begin{array}{l}-0.256^{* * *} \\
(0.0551)\end{array}$ & $\begin{array}{l}-0.113^{* * *} \\
(0.0300)\end{array}$ & $\begin{array}{l}-0.264^{* \star *} \\
(0.0540)\end{array}$ \\
\hline Investment ratio & $\begin{array}{c}0.0175 \\
(0.0134)\end{array}$ & $\begin{array}{l}0.177^{* * *} \\
(0.0276)\end{array}$ & $\begin{array}{c}0.0511 \\
(0.0503)\end{array}$ & $\begin{array}{l}0.513^{\star * *} \\
(0.0796)\end{array}$ & $\begin{array}{c}-0.0155 \\
(0.0492)\end{array}$ & $\begin{array}{c}0.347^{* * *} \\
(0.119)\end{array}$ & $\begin{array}{c}0.0191 \\
(0.0487)\end{array}$ & $\begin{array}{c}0.345^{* * \star} \\
(0.116)\end{array}$ \\
\hline Sales growth & $\begin{array}{l}0.00269^{\star *} \\
(0.00135)\end{array}$ & $\begin{array}{c}0.00317 \\
(0.00275)\end{array}$ & $\begin{array}{l}0.00837^{*} \\
(0.00436)\end{array}$ & $\begin{array}{c}0.00486 \\
(0.00508)\end{array}$ & $\begin{array}{c}0.00212 \\
(0.00382)\end{array}$ & $\begin{array}{r}-0.00295 \\
(0.0101)\end{array}$ & $\begin{array}{c}0.00164 \\
(0.00368)\end{array}$ & $\begin{array}{c}-0.00237 \\
(0.00995)\end{array}$ \\
\hline Age (in logarithm) & $\begin{array}{c}-0.0324^{\star \star} \\
(0.0127)\end{array}$ & $\begin{array}{c}0.00538 \\
(0.00874)\end{array}$ & $\begin{array}{c}-0.0834^{* *} \\
(0.0361)\end{array}$ & $\begin{array}{c}0.0250 \\
(0.0268)\end{array}$ & $\begin{array}{l}-0.0690 \\
(0.0468)\end{array}$ & $\begin{array}{c}-0.0308 \\
(0.0377)\end{array}$ & $\begin{array}{l}-0.0614 \\
(0.0460)\end{array}$ & $\begin{array}{l}-0.0285 \\
(0.0370)\end{array}$ \\
\hline Total assets (in logarithm) & $\begin{array}{l}-0.0185^{\star * *} \\
(0.00230)\end{array}$ & $\begin{array}{l}0.0194^{* * *} \\
(0.00214)\end{array}$ & $\begin{array}{l}-0.0404^{* * *} \\
(0.00855)\end{array}$ & $\begin{array}{l}0.0634^{* \star *} \\
(0.00782)\end{array}$ & $\begin{array}{l}-0.0235^{\star * *} \\
(0.00832)\end{array}$ & $\begin{array}{l}0.0443^{\star * \star} \\
(0.0120)\end{array}$ & $\begin{array}{l}-0.0219^{\star \star \star} \\
(0.00822)\end{array}$ & $\begin{array}{l}0.0442^{* * *} \\
(0.0116)\end{array}$ \\
\hline Private ownership dummy & $\begin{array}{c}0.0123 \\
(0.00923)\end{array}$ & $\begin{array}{l}0.0245^{\star \star} \\
(0.0106)\end{array}$ & $\begin{array}{l}0.0645^{* \star *} \\
(0.0189)\end{array}$ & $\begin{array}{c}0.0653^{\star \star \star} \\
(0.0243)\end{array}$ & $\begin{array}{l}0.0559 \\
(0.0341)\end{array}$ & $\begin{array}{l}0.0328 \\
(0.0273)\end{array}$ & $\begin{array}{l}0.0535 \\
(0.0332)\end{array}$ & $\begin{array}{c}0.0347 \\
(0.0270)\end{array}$ \\
\hline Central SOE dummy & $\begin{array}{l}-0.00297 \\
(0.00920)\end{array}$ & $\begin{array}{l}0.0130 \\
(0.0118)\end{array}$ & $\begin{array}{l}0.00266 \\
(0.0277)\end{array}$ & $\begin{array}{l}0.0176 \\
(0.0328)\end{array}$ & $\begin{array}{l}-0.0177 \\
(0.0367)\end{array}$ & $\begin{array}{l}0.0325 \\
(0.0370)\end{array}$ & $\begin{array}{l}-0.0164 \\
(0.0358)\end{array}$ & $\begin{array}{c}0.0384 \\
(0.0364)\end{array}$ \\
\hline Local SOE dummy & $\begin{array}{c}0.00614 \\
(0.00846)\end{array}$ & $\begin{array}{l}0.0124 \\
(0.0117)\end{array}$ & $\begin{array}{l}0.0478^{*} \\
(0.0245)\end{array}$ & $\begin{array}{l}0.00570 \\
(0.0284)\end{array}$ & $\begin{array}{l}0.0185 \\
(0.0336)\end{array}$ & $\begin{array}{l}0.0356 \\
(0.0338)\end{array}$ & $\begin{array}{l}0.0166 \\
(0.0327)\end{array}$ & $\begin{array}{l}0.0397 \\
(0.0336)\end{array}$ \\
\hline Size of board (in logarithm) & $\begin{array}{l}-0.0132^{*} \\
(0.00676)\end{array}$ & $\begin{array}{l}0.00899 \\
(0.0123)\end{array}$ & $\begin{array}{l}-0.0331^{*} \\
(0.0177)\end{array}$ & $\begin{array}{c}0.0291 \\
(0.0390)\end{array}$ & $\begin{array}{l}-0.0293 \\
(0.0211)\end{array}$ & $\begin{array}{c}-0.0236 \\
(0.0438)\end{array}$ & $\begin{array}{l}-0.0304 \\
(0.0209)\end{array}$ & $\begin{array}{l}-0.0308 \\
(0.0440)\end{array}$ \\
\hline Constant & $\begin{array}{l}0.484^{* * *} \\
(0.0581)\end{array}$ & $\begin{array}{l}-0.528^{\star * *} \\
(0.0681)\end{array}$ & $\begin{array}{c}1.005^{\star * *} \\
(0.215)\end{array}$ & $\begin{array}{c}-1.518^{\star * *} \\
(0.163)\end{array}$ & $\begin{array}{c}1.327^{\star * *} \\
(0.204)\end{array}$ & $\begin{array}{c}-0.527^{\star *} \\
(0.240)\end{array}$ & $\begin{array}{l}1.320^{* * *} \\
(0.201)\end{array}$ & $\begin{array}{c}-0.501^{* *} \\
(0.236)\end{array}$ \\
\hline Number of observations & 15256 & 17475 & 15256 & 17475 & 15256 & 17475 & 15256 & 17475 \\
\hline R2 & 0.0444 & & 0.0481 & & 0.0511 & & 0.0468 & \\
\hline F-test & 22.10 & & 20.08 & & 14.25 & & 12.98 & \\
\hline Number of firms & 2239 & 2382 & 2239 & 2382 & 2239 & 2382 & 2239 & 2382 \\
\hline
\end{tabular}

Note: Standard errors in parentheses. * indicate $\mathrm{p}$ values, ${ }^{*}$ significance at the $10 \%,{ }^{* *}$ at the $5 \%$ and ${ }^{* * *}$ at the $1 \%$ level. Shares held by the ten largest shareholders is the sum of shares held by the ten largest shareholders divided by total outstanding shares. Time-varying explanatory variables in the OLS equations are lagged to reduce the simultaneity problem. Firm, year and industry fixed effects are included in all equations.

Source: Author estimation based on the CSMAR database. 


\section{Institutional investors}

China has been encouraging the participation of institutional investors in the stock market to achieve longterm stability. To examine whether greater ownership by institutional investors improves firm performance, the following equation is estimated, where shareholding by institutional investors, measured as the sum of the shares held by funds divided by total outstanding shares, is the key variable of interest:

$$
\text { Performance }_{i, t}=\alpha+\beta_{1} \text { institutional investors }_{i, t}+\beta_{2} \text { control }_{i, t}+d_{i}+d_{t}+\varepsilon_{i, t}(5)
$$

The presence of institutional investors enhances firm performance (Table 10). The coefficients on this variable are significant at the $1 \%$ level in all eight equations, and the size of the coefficients is large: a one per cent increase in shareholding by institutional investors pushes up productivity by around a fifth of a per cent. The finding is unchanged in the GMM estimation, which accounts for endogeneity. Thus the positive association of shareholding by institutional investors and firm performance is unlikely to be driven by reverse causality, i.e. institutional investors investing in firms that have good governance. Huang and Zhu (2015) showed that foreign institutional investors are effective to perform arms' length monitoring.

\section{Private, foreign and state ownership}

The impact of different types of ownership is examined using dummy variables. Five dummies are defined: (i) foreign, (ii) domestic private, (iii) central SOE, (iv) agency-controlled SOE and (v) local SOE. The foreign firm dummy is used as the base for comparison and therefore omitted. These dummies are applied in all the regressions in this paper and the coefficients are displayed in Tables 4-10. The coefficients on the ownership dummies are rarely significant, but when they are, they are consistent. Domestic private ownership is associated with higher ROE (relative to foreign-invested firms) no matter whether using OLS or GMM and regardless what corporate governance feature enters the equation. Private ownership also leads to higher ROA in case of estimation by GMM, which accounts for endogeneity. Central SOE ownership has a consistent negative impact on productivity in the equations examining the impact of institutional investors on productivity using GMM (Table 10, columns 6 and 8). This means that once shareholding by institutional investors is controlled for, central SOEs exhibit inferior productivity performance relative to foreign-invested firms.

\section{Multiple corporate governance features}

In the above analysis, all corporate governance-related aspects entered the regressions one by one. This was done with the purpose to check whether each of them is relevant for firm performance. In reality, however, multiple corporate governance practices prevail at the same time. Thus, to avoid the omitted variable bias, some variables that were found important in driving corporate performance in the above analysis, were examined by entering them in the same regressions simultaneously. For instance, the impact of institutional investors and that of the share of the ten largest shareholders were entered simultaneously, but the resulting coefficients on these variables or the other control variables did not change sign or their statistical significance was not wiped out. This is true for all the regressions with the four different variables measuring firm performance and both fixed effects and GMM estimation. 
Table 10. Institutional investors and firm performance

\begin{tabular}{|c|c|c|c|c|c|c|c|c|}
\hline & \multicolumn{2}{|c|}{$\mathrm{ROA}$} & \multicolumn{2}{|l|}{ ROE } & \multicolumn{2}{|c|}{ TFP (Olley-Pakes) } & \multicolumn{2}{|c|}{ TFP (OLS with fixed effects) } \\
\hline & $\begin{array}{l}\text { OLS with } \\
\text { fixed } \\
\text { effects }\end{array}$ & GMM & OLS with fixed effects & GMM & OLS with fixed effects & GMM & OLS with fixed effects & GMM \\
\hline & (1) & (2) & (3) & (4) & (5) & (6) & (7) & (8) \\
\hline $\begin{array}{l}\text { Shares held by institutional } \\
\text { investors }\end{array}$ & $\begin{array}{l}0.136^{\star \star *} \\
(0.0111)\end{array}$ & $\begin{array}{l}0.161^{* \star *} \\
(0.0158)\end{array}$ & $\begin{array}{l}0.317^{\star * *} \\
(0.0241)\end{array}$ & $\begin{array}{l}0.366^{\star \star \star} \\
(0.0394)\end{array}$ & $\begin{array}{l}0.263^{\star \star \star} \\
(0.0294)\end{array}$ & $\begin{array}{l}0.219^{\star * *} \\
(0.0359)\end{array}$ & $\begin{array}{l}0.246^{\star * \star} \\
(0.0290)\end{array}$ & $\begin{array}{l}0.203^{\star \star *} \\
(0.0355)\end{array}$ \\
\hline Leverage ratio & $\begin{array}{l}-0.0262^{\star \star \star} \\
(0.00720)\end{array}$ & $\begin{array}{l}-0.136^{* \star \star} \\
(0.0166)\end{array}$ & $\begin{array}{l}0.0132 \\
(0.0227)\end{array}$ & $\begin{array}{l}-0.160^{* \star *} \\
(0.0363)\end{array}$ & $\begin{array}{l}-0.167^{\star \star \star} \\
(0.0281)\end{array}$ & $\begin{array}{l}-0.233^{* * \star} \\
(0.0496)\end{array}$ & $\begin{array}{l}-0.176^{\star \star *} \\
(0.0278)\end{array}$ & $\begin{array}{l}-0.246^{\star \star *} \\
(0.0489)\end{array}$ \\
\hline Investment ratio & $\begin{array}{l}0.00713 \\
(0.0125)\end{array}$ & $\begin{array}{c}0.0879^{* \star *} \\
(0.0239)\end{array}$ & $\begin{array}{c}0.0505 \\
(0.0332)\end{array}$ & $\begin{array}{l}0.345^{* \star *} \\
(0.0716)\end{array}$ & $\begin{array}{c}-0.0534 \\
(0.0511)\end{array}$ & $\begin{array}{c}0.0149 \\
(0.0961)\end{array}$ & $\begin{array}{l}-0.0174 \\
(0.0505)\end{array}$ & $\begin{array}{c}0.0326 \\
(0.0911)\end{array}$ \\
\hline Sales growth & $\begin{array}{l}0.00171^{*} \\
(0.000906)\end{array}$ & $\begin{array}{l}0.00374^{*} \\
(0.00213)\end{array}$ & $\begin{array}{l}0.00456^{*} \\
(0.00241)\end{array}$ & $\begin{array}{c}0.0119^{*} \\
(0.00655)\end{array}$ & $\begin{array}{c}0.00285 \\
(0.00235)\end{array}$ & $\begin{array}{c}0.0110^{\star} \\
(0.00612)\end{array}$ & $\begin{array}{c}0.00234 \\
(0.00209)\end{array}$ & $\begin{array}{l}0.0115^{\star} \\
(0.00611)\end{array}$ \\
\hline Age (in logarithm) & $\begin{array}{c}-0.0452^{* * *} \\
(0.0104)\end{array}$ & $\begin{array}{l}-0.0149^{* *} \\
(0.00749)\end{array}$ & $\begin{array}{l}-0.105^{\star \star \star} \\
(0.0272)\end{array}$ & $\begin{array}{c}-0.0757^{* * *} \\
(0.0246)\end{array}$ & $\begin{array}{l}-0.0878^{* *} \\
(0.0391)\end{array}$ & $\begin{array}{l}-0.0458 \\
(0.0368)\end{array}$ & $\begin{array}{l}-0.0767^{\star *} \\
(0.0381)\end{array}$ & $\begin{array}{l}-0.0454 \\
(0.0359)\end{array}$ \\
\hline Total assets (in logarithm) & $\begin{array}{l}-0.0136^{* * *} \\
(0.00206)\end{array}$ & $\begin{array}{l}0.0164^{\star \star *} \\
(0.00227)\end{array}$ & $\begin{array}{l}-0.0322^{* \star *} \\
(0.00509)\end{array}$ & $\begin{array}{l}0.0405^{\star * \star} \\
(0.00653)\end{array}$ & $\begin{array}{l}-0.0138^{*} \\
(0.00771)\end{array}$ & $\begin{array}{l}0.0256^{\star * \star} \\
(0.00762)\end{array}$ & $\begin{array}{l}-0.0127^{*} \\
(0.00743)\end{array}$ & $\begin{array}{l}0.0263^{* \star *} \\
(0.00749)\end{array}$ \\
\hline Private ownership dummy & $\begin{array}{c}0.0162^{*} \\
(0.00873)\end{array}$ & $\begin{array}{c}0.0111 \\
(0.00716)\end{array}$ & $\begin{array}{c}0.0500^{* * \star} \\
(0.0181)\end{array}$ & $\begin{array}{c}0.0732^{\star \star \star} \\
(0.0268)\end{array}$ & $\begin{array}{c}0.0158 \\
(0.0334)\end{array}$ & $\begin{array}{l}-0.0177 \\
(0.0242)\end{array}$ & $\begin{array}{c}0.0157 \\
(0.0323)\end{array}$ & $\begin{array}{l}-0.0179 \\
(0.0240)\end{array}$ \\
\hline Central SOE dummy & $\begin{array}{l}-0.00670 \\
(0.00908)\end{array}$ & $\begin{array}{l}-0.0152 \\
(0.00961)\end{array}$ & $\begin{array}{l}-0.0181 \\
(0.0251)\end{array}$ & $\begin{array}{c}0.0343 \\
(0.0436)\end{array}$ & $\begin{array}{l}-0.0463 \\
(0.0358)\end{array}$ & $\begin{array}{c}-0.0729^{* *} \\
(0.0343)\end{array}$ & $\begin{array}{l}-0.0424 \\
(0.0350)\end{array}$ & $\begin{array}{l}-0.0698^{\star *} \\
(0.0337)\end{array}$ \\
\hline $\begin{array}{l}\text { Agency-controlled SOE } \\
\text { dummy }\end{array}$ & $\begin{array}{c}0.000431 \\
(0.0140)\end{array}$ & $\begin{array}{l}-0.0258 \\
(0.0169)\end{array}$ & $\begin{array}{l}0.00861 \\
(0.0328)\end{array}$ & $\begin{array}{c}-0.00415 \\
(0.0461)\end{array}$ & $\begin{array}{l}-0.0105 \\
(0.0489)\end{array}$ & $\begin{array}{l}-0.0780 \\
(0.0635)\end{array}$ & $\begin{array}{l}-0.0106 \\
(0.0481)\end{array}$ & $\begin{array}{l}-0.0821 \\
(0.0642)\end{array}$ \\
\hline Local SOE dummy & $\begin{array}{l}-0.000555 \\
(0.00891)\end{array}$ & $\begin{array}{l}-0.00744 \\
(0.00802)\end{array}$ & $\begin{array}{c}0.0237 \\
(0.0200)\end{array}$ & $\begin{array}{c}0.0516 \\
(0.0358)\end{array}$ & $\begin{array}{l}-0.00490 \\
(0.0312)\end{array}$ & $\begin{array}{l}-0.0253 \\
(0.0297)\end{array}$ & $\begin{array}{l}-0.00369 \\
(0.0304)\end{array}$ & $\begin{array}{l}-0.0233 \\
(0.0289)\end{array}$ \\
\hline Size of board (in logarithm) & $\begin{array}{c}0.00421 \\
(0.00588)\end{array}$ & $\begin{array}{c}0.0102 \\
(0.00912)\end{array}$ & $\begin{array}{c}0.0159 \\
(0.0158)\end{array}$ & $\begin{array}{c}0.0207 \\
(0.0273)\end{array}$ & $\begin{array}{c}0.0127 \\
(0.0212)\end{array}$ & $\begin{array}{c}-0.00489 \\
(0.0290)\end{array}$ & $\begin{array}{c}0.0117 \\
(0.0208)\end{array}$ & $\begin{array}{l}-0.0115 \\
(0.0290)\end{array}$ \\
\hline Constant & $\begin{array}{l}0.461^{* * *} \\
(0.0530)\end{array}$ & $\begin{array}{c}-0.278^{* * *} \\
(0.0566)\end{array}$ & $\begin{array}{l}1.002^{* * *} \\
(0.129)\end{array}$ & $\begin{array}{c}-0.733^{* * *} \\
(0.154)\end{array}$ & $\begin{array}{c}1.354^{* * *} \\
(0.188)\end{array}$ & $\begin{array}{c}0.222 \\
(0.230)\end{array}$ & $\begin{array}{c}1.339^{* * *} \\
(0.183)\end{array}$ & $\begin{array}{c}0.279 \\
(0.221)\end{array}$ \\
\hline Number of observations & 12049 & 13982 & 12049 & 13982 & 12049 & 13982 & 12049 & 13982 \\
\hline $\mathrm{R} 2$ & 0.0814 & & 0.0680 & & 0.0577 & & 0.0525 & \\
\hline F-test & 20.05 & & 19.37 & & 12.25 & & 11.49 & \\
\hline Number of firms & 2205 & 2374 & 2205 & 2374 & 2205 & 2374 & 2205 & 2374 \\
\hline
\end{tabular}

Note: Standard errors in parentheses * indicate p values, * significance at the $10 \%$, ** at the $5 \%$ and ${ }^{* * *}$ at the $1 \%$ level. The shares held by institutional investors is the sum of shares held by institutional investors divided by total outstanding shares. Time-varying explanatory variables in the OLS equations are lagged to reduce the simultaneity problem. Firm, year and industry fixed effects are included in all equations.

Source: Authors' estimation based on the CSMAR database. 


\section{Wrapping up}

In sum, the empirical analysis carried out in this study confirms that certain corporate governance practices affect firm performance in China. After controlling for endogeneity, the share of independent directors does ot appear to affect firm performance. When the requirement that at least one third of directors must be independent was introduced in 2002, however, profitability improved. Thus the finding in the international literature with regard to the ambiguous impact of independent directors on corporate performance is confirmed, though it may be related to the fact that independent directors in China are not truly independent. The size of the board does not appear to affect performance, again, confirming the unambiguity in the literature. Having the same person as the director of the board and the CEO does not seem to affect firm performance, consistent with earlier studies.

Incentive mechanisms such as the salary gap between executives and workers matters but shareholding by executives not so much. The salary gap negatively affects productivity but positively affects returns on assets and equity, probably implying that while executives may be incentivised to maximise profits (which are often linked to their salaries), they may do this by resorting to measures that are detrimental to productivity such as mere volume-based expansion or "buying" growth by higher debt. Executive shareholding does not appear to affect firm performance, possibly because of the still relatively infrequent rewarding of executives in the form of company shares.

Ownership structures also matter, in particular ownership concentration (captured by shareholding by the largest and by the ten largest shareholders), shareholding by institutional investors and private versus various forms of State ownership. The findings corroborate the view that over-concentration harms firm performance but that a certain degree of concentration is beneficial. Institutional investors have a large positive impact on firm performance. Five ownership types are distinguished to assess their effect on firm performance. Although the coefficients on the ownership dummies are seldom significant, they are consistent across the paper when they are. For instance, private ownership appears to positively affect firm performance, and conversely for ownership by central SOEs.

Looking forward, further investigation of the impact of ownership types on firm performance might provide more insights. With the expected changes in China's Corporate Governance Code, new avenues may open up for research. 


\section{REFERENCES}

Allen, F., J. Qian and M. Qian (2005), "Law, finance and economic growth in China”, Journal of Financial Economics, Vol. 77.

Chen, T. (2015), "Institutions, board structure, and corporate performance: Evidence from Chinese firms", Journal of Corporate Finance, Vol. 32.

Clark, A.E., N. Kristensen and N. Westergard-Nielsen (2009), "Job satisfaction and co-worker wages: status or signal?", Economic Journal, Vol. 119.

Conyon, M. J. and L. He (2011), Executive compensation and corporate governance in China, Institute for compensation Studies, Cornell University ILR School.

Conyon, M.J. and K.J. Murphy (2000), "The prince and the pauper? CEO pay in the United States and United Kingdom", The Economic Journal, Vol. 110(467).

Firth, M., T.Y. Leung, O.M. Rui and C. Na (2015), "Relative pay and its effects on firm efficiency in a transitional economy", Journal of Economic Behavior and Organization, Vol. 110.

He, Y., Y. Chiu and B. Zhang (2015), "The Impact of corporate governance on state-owned and non-stateowned firms' efficiency in China", North American Journal of Economics and Finance, Vol. 33.

Huang, W. and T. Zhu (2015), "Foreign institutional investors and corporate governance in emerging markets: Evidence of a split-share structure reform in China", Journal of Corporate Finance, Vol. 32.

Isaksson, M. and S. Çelik (2012) "Who cares? Corporate governance in today's equity markets", OECD Corporate Governance Working Papers, No. 8, OECD Publishing, Paris. http://dx.doi.org/10.1787/5k47zw5kdnmp-en

Jensen, M.C. and W.H. Meckling (1976), "Theory of the firm - managerial behaviour, agency costs and ownership structure", Journal of Financial Economics, Vol. 3(4).

Jiang, F. and K.A. Kim (2015), "Corporate governance in China: A modern perspective", Journal of Corporate Finance, Vol. 32.

Jiang, G.H., P.G. Rao and H. Yue (2015), "Tunnelling through non-operational fund occupancy: An investigation based on officially identified activities", Journal of Corporate Finance, Vol. 32, June.

Li, K., L. Lu, U.R. Mittoo and Z. Zhang (2015), "Board independence, ownership concentration and corporate performance - Chinese evidence", International Review of Financial Analysis, Vol. 41.

Linck, J.S., J.M. Netter and T. Yang (2008), “The determinants of board structure", Journal of Financial Economics, Vol. 87(2).

Liu, Y., M.K. Miletkov, Z. Wei and T. Yang (2015), "Board independence and firm performance in China", Journal of Corporate Finance, Vol. 30.

Main, B.G.M., C.A. O’Reilly III and J. Wade (1993), “Top executive pay: Tournament or teamwork?”, Journal of Labour Economics, Vol. 11(4). 
Miles, L. and M. He (2005), "Protecting the rights and interests of minorities shareholders in listed companies in China: Challenge for the future", International Company and Commercial Law Review, Vol. 16.

Molnár, M. (2017), "Boosting firm dynamism and performance in China", OECD Economics Department Working Papers, No. 1408.

Murphy, K.J. (1999), “Executive compensation”, Chapter 38 in Handbook of Labor Economics, Vol. 3b, Elsevier.

OECD (2017), Economic Survey of China, OECD Publishing, Paris.

OECD (2015b), G20/OECD Principles of Corporate Governance, OECD Publishing, Paris.

OECD (2015c), "Growth companies, access to capital markets and corporate governance", OECD report to G20 Finance Ministers and Central Bank Governors available at https://www.oecd.org/g20/topics/framework-strong-sustainable-balanced-growth/OECD-GrowthCompanies-Access-to-Capital-Markets-and-Corporate-Governance.pdf accessed on 18 October, 2016.

OECD (2015d), OECD Economic Surveys: China, OECD Publishing, Paris.

OECD (2015e), OECD Guidelines on Corporate Governance of State-Owned Enterprises, OECD Publishing, Paris.

OECD (2014b), Public Enforcement and Corporate Governance in Asia - Guidance and Good Practices, OECD Publishing, Paris.

OECD (2013), Better Policies for Board Nomination and Election in Asia, OECD Publishing, Paris.

OECD (2011), Corporate Governance of Listed Companies in China - Self-Assessment by the China Securities Regulatory Commission, OECD Publishing, Paris.

Olley, G.S. and A. Pakes (1996), "The dynamics of productivity in the telecommunications equipment industry", Econometrica, Vol. 64(6).

Pettman, J. and N. Lamjav (2009), "The Evolution of Corporate Governance in China - The effects of ownership on Chinese listed companies", Copenhagen Business School Finance \& Strategic Management Master's Thesis.

Shleifer, A. and R.W. Vishny (1997), “A survey of corporate governance”, Journal of Finance, 52(2).

Wintoki, M.B., J.S. Linck and J.M. Netter (2012), "Endogeneity and the dynamics of internal corporate governance", Journal of Financial Economics, Vol. 105(3).

Wu, W., C. Wu and O. M. Rui (2012), "Ownership and the value of political connections: Evidence from China”, European Financial Management, Vol. 18(4).

Yang, J. (2005), "Comparative corporate governance: reforming Chinese corporate governance", International Company and Commercial Law Review, Vol. 16.

Ye, K., J. Zhu, Z. Lu and R. Zhang (2011), "Duli dongshi de dulixing jiyu dongshihui toupiaode zhengju" in Chinese, The independence of independent directors: Evidence from board voting behaviour, Jingji Yanjiu (Economic Research Journal), Vol. 2011(1). 
Zhang, L. (2012), Venture Capital and Corporate Governance of Chinese Listed Companies, Springer Publishing.

Zhang, X. and W. Xie (2000), “Zhongguode duli kuaiji biaozhun”, in Chinese, "The independent auditing standards in China", Kuaiji Shiye, Vol. 64.

Zhou, T. (2014), "Legal regulation of China's securities markets - Recent improvements and competing advantages" in M. Faure and G. Xu (eds.), Economics and Regulation in China, Routledge.

Zhu, J., K. Ye, J.W. Tucker and K.J.C. Chan (2016), "Board hierarchy, independent directors, and firm value: Evidence from China", Journal of Corporate Finance, Vol. 41. 
ECO/WKP(2017)53

\section{ANNEX FIGURES}

Figure A.1. Listed firm performance by size, age, listing history, sector and ownership Performance measured by TFP growth, ROA and ROE, 2010

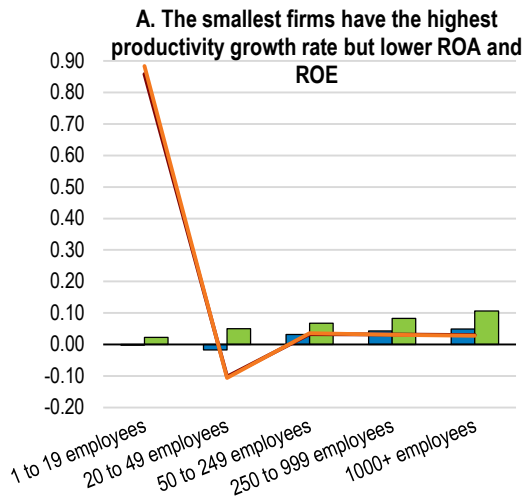

C. Recently listed firms have the highest ROA and $\mathrm{ROE}$, but the lowest productivity growth

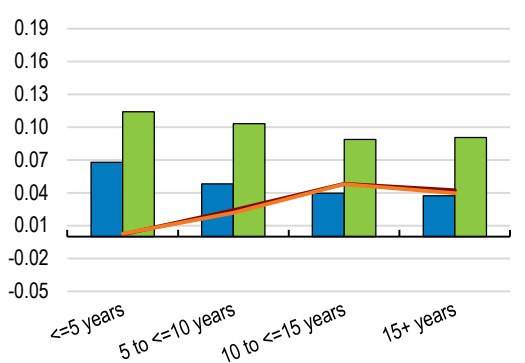

E. Domestic private firms perform best on all measures

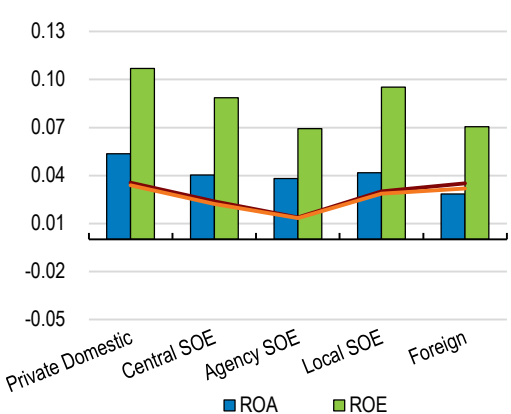

B. Younger companies tend to perform better on ROA but worse on productivity growth $0.80 \quad 0.20$ $\begin{array}{ll}0.80 & 0.20 \\ 0.70 & 0.15\end{array}$ $0.600 .15 \longrightarrow 0.15$ $0.10 \square$
$0.40 \quad \square$ 30.05 0.20 $0.10 \quad 0.00$ $-0.10-0.05$ $-0.05$ $-0.10$ $<=5 y^{e^{a r s}} \quad 5$ to $<=10$ years 10 to $<=15 y$ years $\quad 15+y$ ears $\quad-0.10$

\section{Utilities have the highest ROA, commercial} firms the highest ROE and industrial firms the highest productivity growth rate

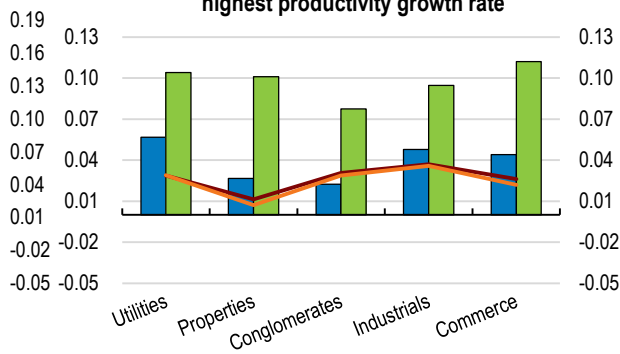

F. Non-SOEs perform better

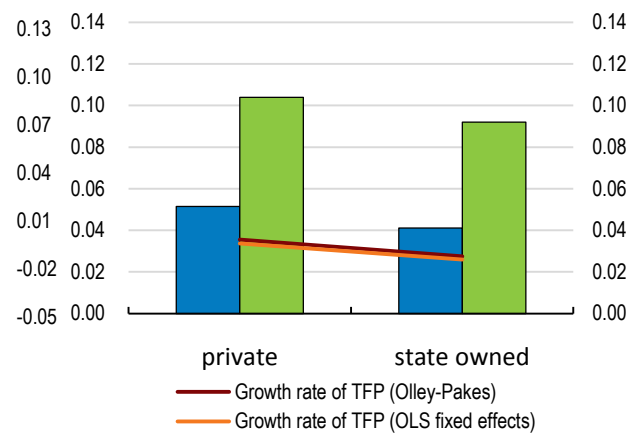

Note: ROA is net income divided by total assets, ROE is net income divided by shareholders' equity, TFP (Olley-Pakes) is TFP estimated by the Olley-Pakes method taking into account endogeneity, TFP (OLS fixed effects) is TFP estimated using OLS with fixed effects and thus partially accounting for endogeneity. In Panel D, conglomerates refer (i) either to firms in sectors that do not belong to utilities, property, industrials or commerce or (ii) to firms where the main activity produced less than half of revenues. In Panel $\mathrm{E}$, central SOEs refer to SOEs managed by SASAC and the Ministry of Finance, agency SOEs to SOEs under government agencies and local SOEs managed by local SASACs. In Panel F, State-owned refers to state-controlled firms, including with absolute majority ownership and without absolute majority ownership but relative control power by the State.

Source: Authors' calculation based on the CSMAR database. 
Figure A.2. Listed firm performance by size, age, listing history and ownership

Performance measured by TFP growth, ROA and ROE, 2005

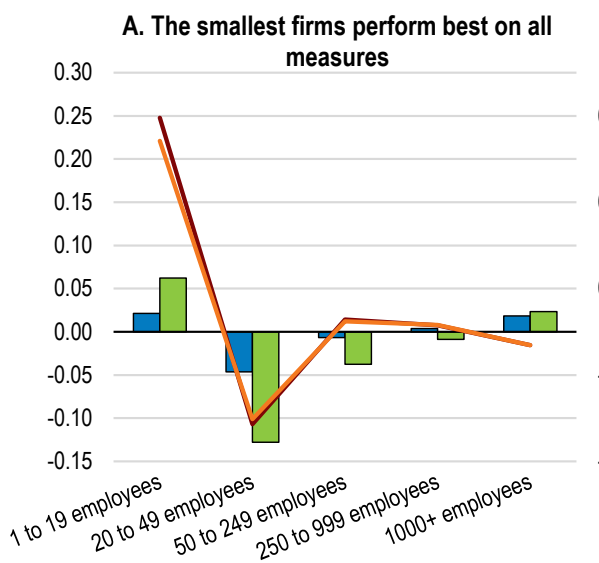

C. Recently listed companies have the lowest productivity growth but the highest ROA and ROE

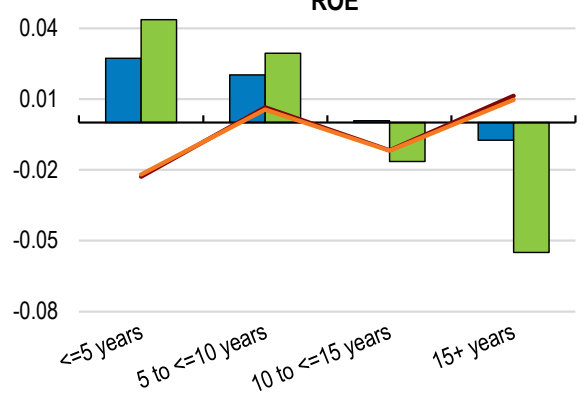

E. Central SOEs have the highest ROA and ROE, while local SOEs have the highest

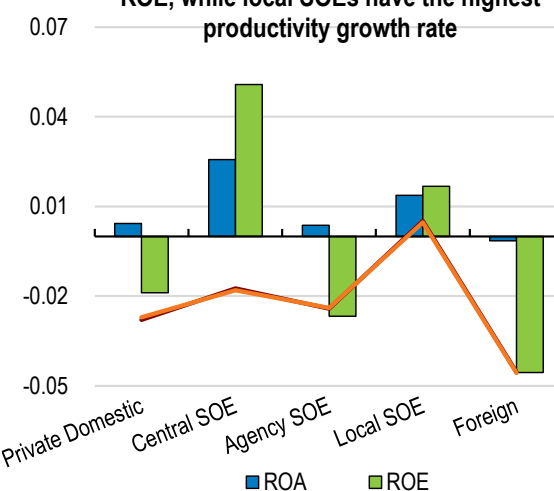

B. The youngest and the oldest companies have the lowest productivity growth rate

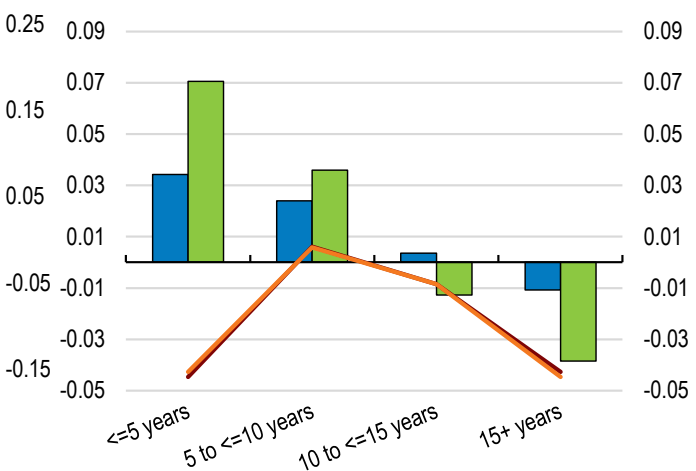

D. Property companies havs the highest productivity growth rate but the lowest ROA

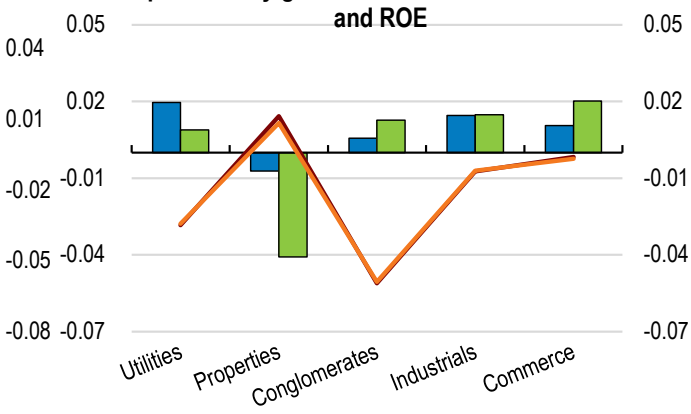

F. SOEs perform better

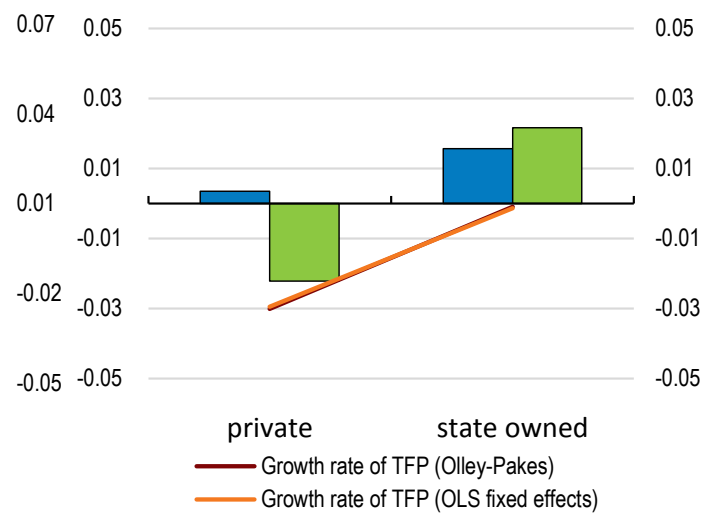

Note: ROA is net income divided by total assets, ROE is net income divided by shareholders' equity, TFP (Olley-Pakes) is TFP estimated by the Olley-Pakes method taking into account endogeneity, TFP (OLS fixed effects) is TFP estimated using OLS with fixed effects and thus partially accounting for endogeneity. In Panel D, conglomerates refer (i) either to firms in sectors that do not belong to utilities, property, industrials or commerce or (ii) to firms where the main activity produced less than half of revenues. In Panel E, central SOEs refer to SOEs managed by SASAC and the Ministry of Finance, agency SOEs to SOEs under government agencies and local SOEs managed by local SASACs. In Panel F, State-owned refers to state-controlled firms, including with absolute majority ownership and without absolute majority ownership but relative control power by the State.

Source: Authors' calculation based on the CSMAR database. 
ECO/WKP(2017)53

Figure A.3. Listed firm performance by size, age, listing history, sector and ownership

Performance measured by TFP growth, ROA and ROE, 2000

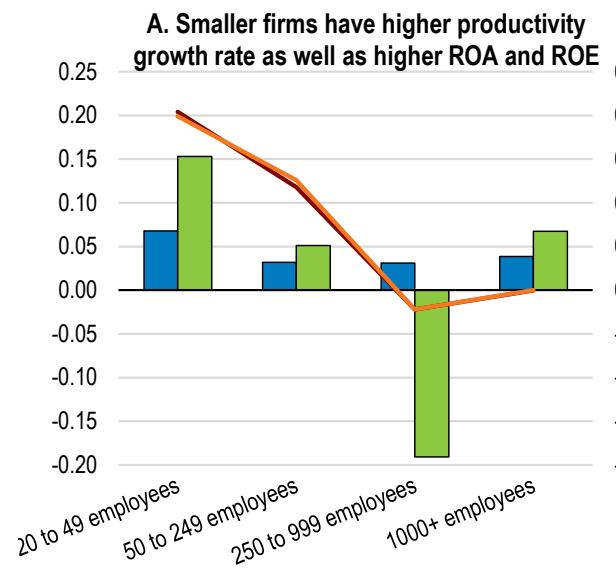

C. Recently listed companies have the highest ROA and ROE but the lowest productivity

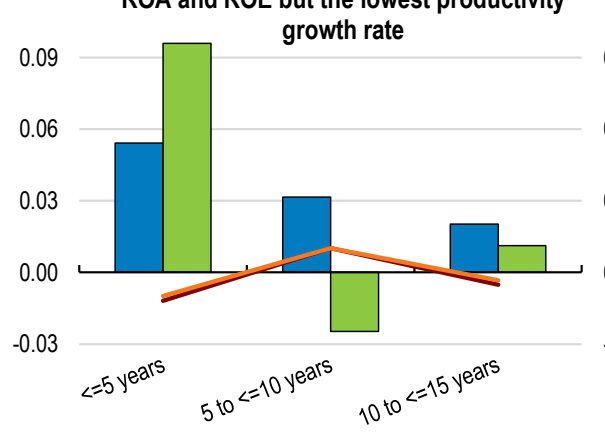

E. Agency-controlled SOEs have the highest TFP growthfollowed by domestic private and

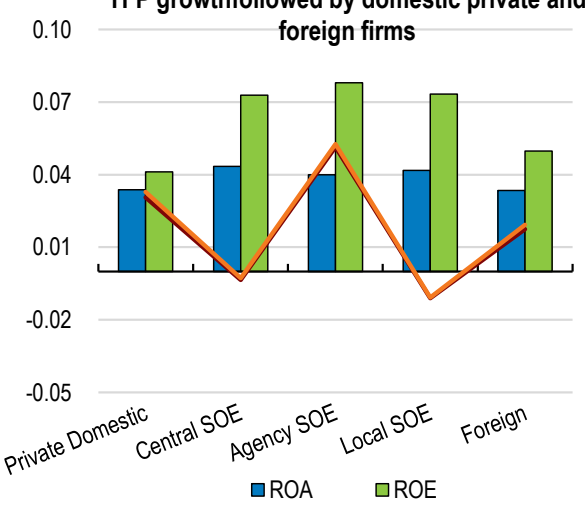

B. The oldest companies tend to perform best on ROE and productivity growth

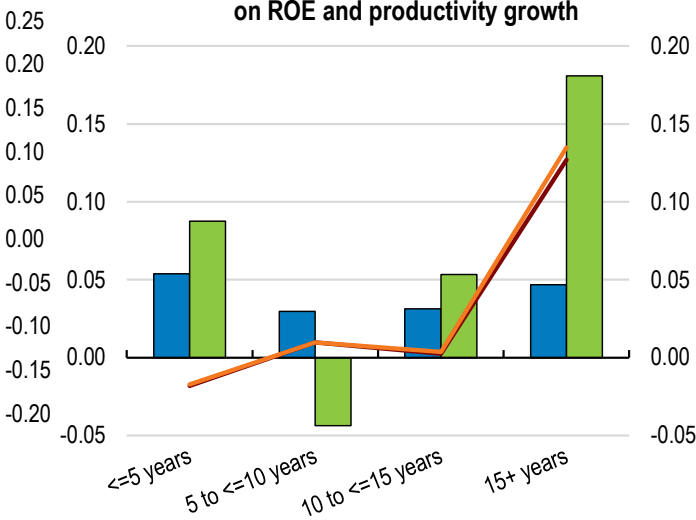

D. Industrial companies have the highest ROA and ROE, while property companies the

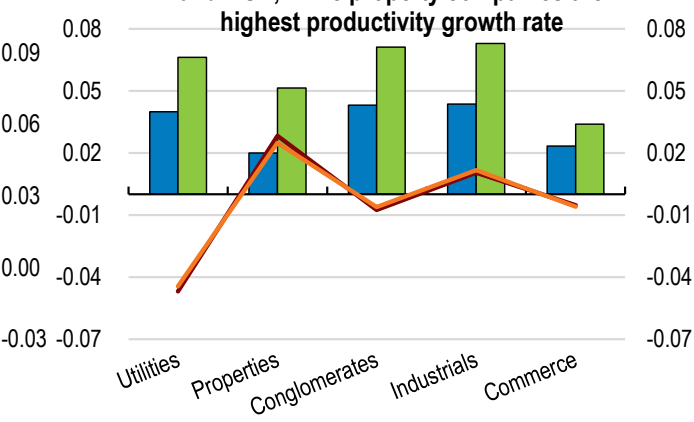

F. SOEs have a lower growth rate of productivity

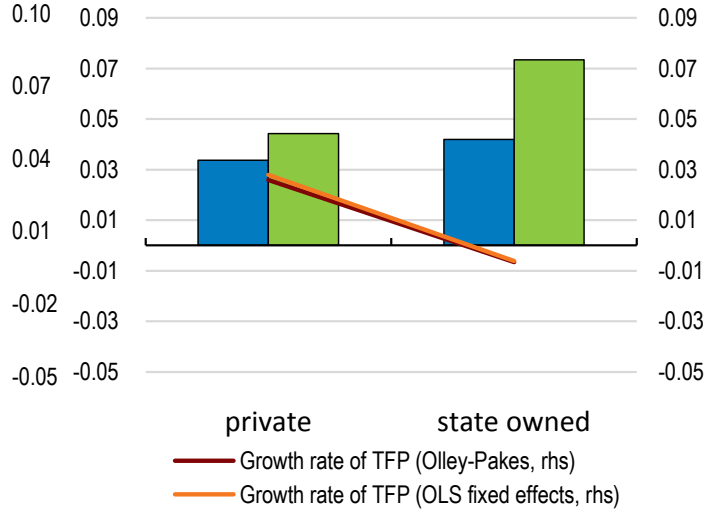

Note: ROA is net income divided by total assets, ROE is net income divided by shareholders' equity, TFP (Olley-Pakes) is TFP estimated by the Olley-Pakes method taking into account endogeneity, TFP (OLS fixed effects) is TFP estimated using OLS with fixed effects and thus partially accounting for endogeneity. In Panel D, conglomerates refer (i) either to firms in sectors that do not belong to utilities, property, industrials or commerce or (ii) to firms where the main activity produced less than half of revenues. In Panel E, central SOEs refer to SOEs managed by SASAC and the Ministry of Finance, agency SOEs to SOEs under government agencies and local SOEs managed by local SASACs. In Panel F, State-owned refers to state-controlled firms, including with absolute majority ownership and without absolute majority ownership but relative control power by the State.

Source: Authors' calculation based on the CSMAR database. 
Figure A.4. Evolution of productivity of listed firms by size, age, listing history, sector and ownership Performance measured by TFP growth estimated by the Olley-Pakes method, 1999-2015

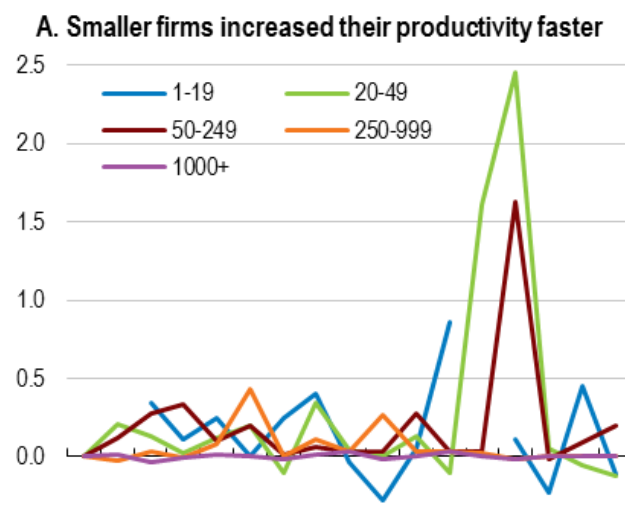

$-0.5$
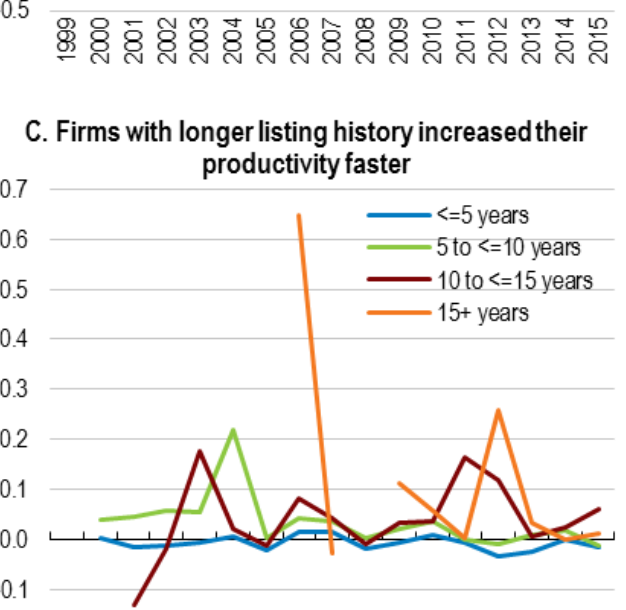

$-0.2$

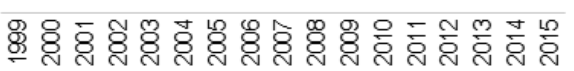

B. The older firms increased their productivity faster

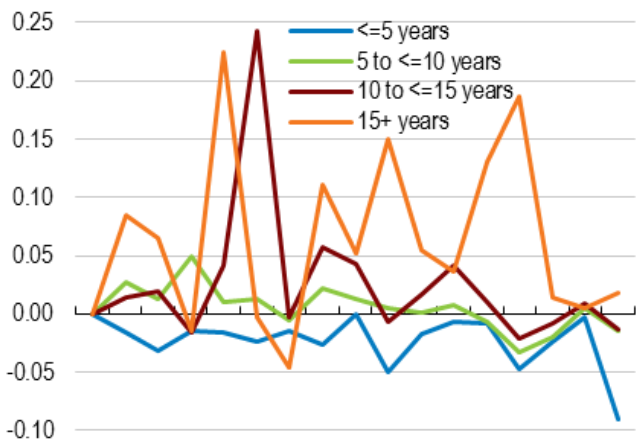

$-0.15$

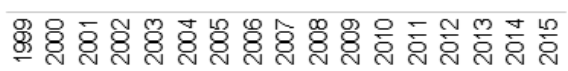

D. Commercials and property firms experienced

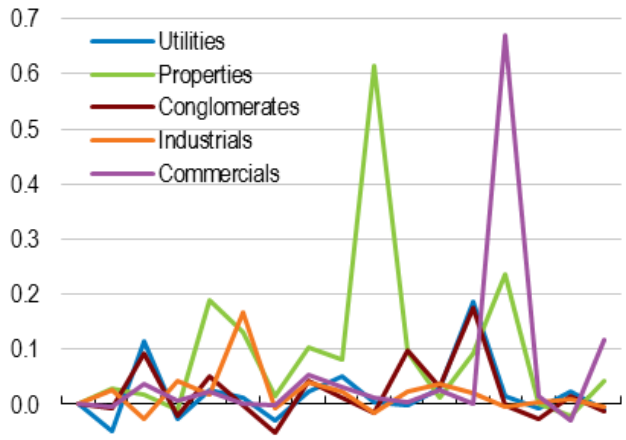

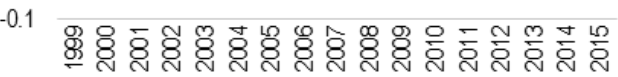

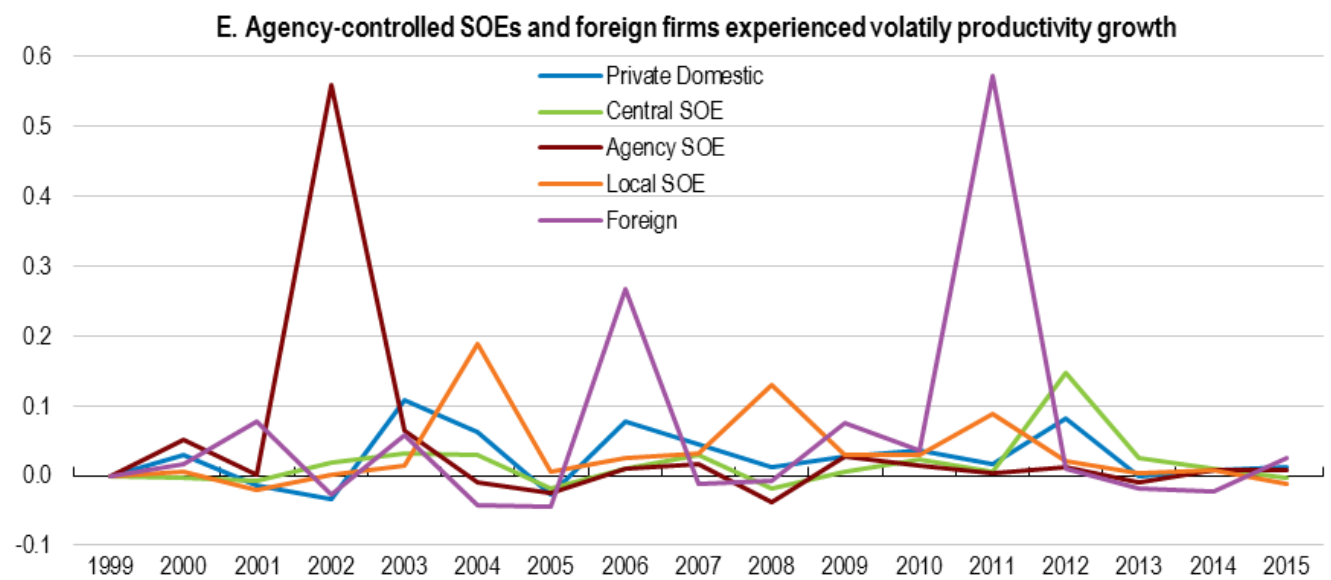

Note: TFP is estimated by the Olley-Pakes method taking into account endogeneity, In Panel D, conglomerates refer (i) either to firms in sectors that do not belong to utilities, property, industrials or commerce or (ii) to firms where the main activity produced less than half of revenues. In Panel E, central SOEs refer to SOEs managed by SASAC and the Ministry of Finance, agency SOEs to SOEs under government agencies and local SOEs managed by local SASACs. In Panel F, State-owned refers to state-controlled firms, including with absolute majority ownership and without absolute majority ownership but relative control power by the State.

Source: Authors' calculation based on the CSMAR database. 
Table A.1. List of variables used in the analysis

\section{Performance variables}

\section{TFP fixed effects}

TFP Olley-Pakes

\section{ROA}

ROE

\section{Control variables}

Leverage ratio

Investment ratio

Sales growth

Total assets

Age

Listed age

\section{Corporate governance variables}

Size of the board

total number of directors

Share of independent directors

Salary gap

Executive shareholding

Shares held by the largest shareholder

Shares held by the ten largest shareholders

Shares held by institutional investors estimated total factor productivity using OLS with fixed effects

estimated total factor productivity using the Olley-Pakes method

net income divided by total assets

net income divided by shareholders' equity

total liabilities divided by total assets

fixed, intangible and other long-term asset purchases divided by total assets

growth rate of total sales

total assets in the balance sheet

number of years since the establishment of the firm

number of years since the listing of the firm

number of independent directors divided by total number of directors

average salary of executives divided by average wage of staff

shares held by executives divided by total outstanding shares

shares held by the largest shareholder divided by total outstanding shares

sum of shares held by the ten largest shareholders divided by total outstanding shares

sum of shares held by institutional investors divided by total outstanding shares 